\title{
Thermal structure and exhumation history of the Lesser Himalaya in central Nepal
}

\author{
L. Bollinger, ${ }^{1,2}$ J. P. Avouac, ${ }^{1,2}$ O. Beyssac, ${ }^{3}$ E. J. Catlos,${ }^{4}$ T. M. Harrison, ${ }^{4}$ M. Grove, ${ }^{4}$ \\ B. Goffé, ${ }^{3}$ and S. Sapkota ${ }^{5}$
}

Received 20 July 2003; revised 15 July 2004; accepted 19 July 2004; published 20 October 2004.

[1] The Lesser Himalaya (LH) consists of metasedimentary rocks that have been scrapped off from the underthrusting Indian crust and accreted to the mountain range over the last $\sim 20$ Myr. It now forms a significant fraction of the Himalayan collisional orogen. We document the kinematics and thermal metamorphism associated with the deformation and exhumation of the LH, combining thermometric and thermochronological methods with structural geology. Peak metamorphic temperatures estimated from Raman spectroscopy of carbonaceous material decrease gradually from $520^{\circ}-550^{\circ} \mathrm{C}$ below the Main Central Thrust zone down to less than $330^{\circ} \mathrm{C}$. These temperatures describe structurally a $20^{\circ}-$ $50^{\circ} \mathrm{C} / \mathrm{km}$ inverted apparent gradient. The Ar muscovite ages from LH samples and from the overlying crystalline thrust sheets all indicate the same regular trend; i.e., an increase from about 34 Ma near the front of the high range to about 20 Ma near the leading edge of the thrust sheets, about $80 \mathrm{~km}$ to the south. This suggests that the LH has been exhumed jointly with the overlying nappes as a result of overthrusting by about $5 \mathrm{~mm} / \mathrm{yr}$. For a convergence rate of about $20 \mathrm{~mm} / \mathrm{yr}$, this implies underthrusting of the Indian basement below the Himalaya by about $15 \mathrm{~mm} / \mathrm{yr}$. The structure, metamorphic grade and exhumation history of the LH supports the view that, since the mid-Miocene, the Himalayan orogen has essentially grown by underplating, rather than by frontal accretion. This process has resulted from duplexing at a depth close to the brittle-ductile transition zone, by southward migration of a midcrustal ramp along the Main Himalayan Thrust fault, and is estimated to have resulted in a net flux

\footnotetext{
${ }^{1}$ Laboratoire Détection et Géophysique, Commissariat à l'Energie Atomique, Bruyères le Châtel, France.

${ }^{2}$ Also at Division of Geological and Planetary Sciences, California Institute of Technology, Pasadena, California, USA.

${ }^{3}$ Ecole Normale Supérieure, Laboratoire de Géologie, Paris, France.

${ }^{4}$ Institute of Geophysics and Planetary Physics, University of California, Los Angeles, California, USA.

${ }^{5}$ Department of Mines and Geology, National Seismic Center, Lainchur, Kathmandu, Nepal.

Copyright 2004 by the American Geophysical Union. 0278-7407/04/2003TC001564\$12.00
}

of up to $150 \mathrm{~m}^{2} / \mathrm{yr}$ of $\mathrm{LH}$ rocks into the Himalayan orogenic wedge. The steep inverse thermal gradient across the LH is interpreted to have resulted from a combination of underplating and post metamorphic shearing of the underplated units. INDEX TERMS: 8102 Tectonophysics: Continental contractional orogenic belts; 8122 Tectonophysics: Dynamics, gravity and tectonics; 9320 Information Related to Geographic Region: Asia; KEYWORDS: Himalaya, thermal structure, underplating, duplex, metamorphism, thermochronology. Citation: Bollinger, L., J. P. Avouac, O. Beyssac, E. J. Catlos, T. M. Harrison, M. Grove, B. Goffé, and S. Sapkota (2004), Thermal structure and exhumation history of the Lesser Himalaya in central Nepal, Tectonics, 23, TC5015, doi:10.1029/2003TC001564.

\section{Introduction}

[2] As early as the mid-nineteenth century, field geologists noticed the upward increase of metamorphic grade across the Himalaya [Mallet, 1874; Medlicott, 1864; Oldham, 1883]. A number of field studies have since documented this apparently inverted gradient together with the structural architecture of the range [e.g., Hodges et al., 1996; Pêcher, 1975; Stephenson et al., 2000]. The inverted gradient is most obvious within and close to the Main Central Thrust (MCT) zone which marks the contact between the High Himalayan Crystalline units (HHC) and the Lesser Himalaya (LH). Metamorphic grade increases upward from chlorite, to biotite, garnet, kyanite and sillimanite-grade rocks over a structural distance of a few kilometers [e.g., Pêcher, 1989]. This observation has been interpreted either as evidence for a thermal structure with recumbent isotherms [e.g., Le Fort, 1975], or as the result of postmetamorphic shearing of isograds [e.g., Brunel et al., 1979; Hubbard, 1996] and has stimulated a variety of thermal modeling [Harrison et al., 1998; Henry et al., 1997; Jaupart and Provost, 1985; Molnar and England, 1990; Royden, 1993]. The exhumation history of the crystalline nappes in the study area was also studied by various authors [Arita et al., 1997; Macfarlane et al., 1992; P. Copeland, personal communication]. By contrast, the metamorphic and exhumation history of the Lesser Himalaya remains poorly documented mainly because of the poor mineralogy of these rocks and their supposed low metamorphic grade. However, this information is critical to test models of mountain building in the Himalayas. Indeed, the LH thrust sheets form the 


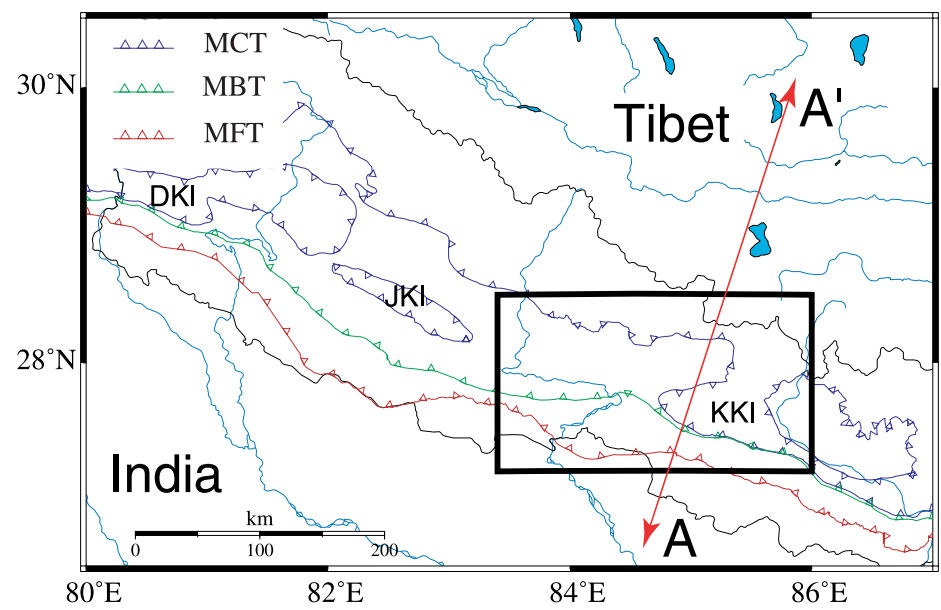

a

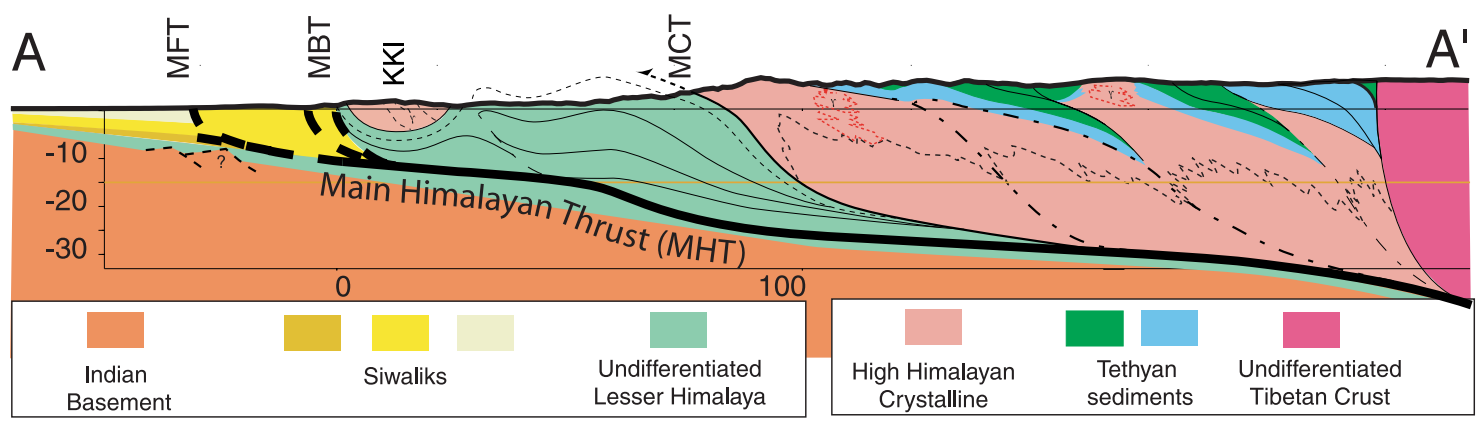

b

Figure 1. (a) Simplified geological map of Nepal with location of study area (box) shown in Figure 2 and of cross section $\mathrm{AA}^{\prime}$ (Figure 1b). (b) N018 ${ }^{\circ} \mathrm{E}$ geological section across the Himalaya of west central Nepal. Abbreviations are as follows: DKl, Dadeldhura klippe; JKl, Jajarkot klippe; KKl, Kathmandu klippe; MFT, Main Frontal Thrust fault; MBT, Main Boundary Thrust fault; MCT, Main Central Thrust fault. All these faults are thought to sole into a basal thrust fault called here the Main Himalayan Thrust (MHT), which would correspond with the midcrustal reflector imaged below southern Tibet from the INDEPTH experiment [Hauck et al., 1998].

bulk of the Himalayan wedge that have been accreted to the range over the last $\sim 10 \mathrm{Myr}$ as suggested from structural and sedimentological investigations [DeCelles et al., 2000; Huyghe et al., 2001; Robinson et al., 2001; Schelling and Arita, 1991].

[3] In this paper we focus our effort on the LH, most specifically in the area of central Nepal, west of Kathmandu. To document the thermal structure, we take advantage of new temperature data obtained from the degree of graphitization of carbonaceous material [Beyssac et al., 2004], a technique which was found to be particularly appropriate in the case of $\mathrm{LH}$. We analyze these data in view of their structural setting, together with ${ }^{40} \mathrm{Ar} /{ }^{39} \mathrm{Ar}$ cooling ages determined for white micas. We show that these data can be interpreted from a kinematic model according to which the Himalaya, since the late Miocene times, would have grown primarily by underplating near the brittle-ductile transition.

\section{Geological Setting}

\subsection{Key Structural Features Across the Himalaya of West Central Nepal}

[4] To the first order, the Himalaya has resulted from crustal-scale thrusting on a few major thrust faults (Figure 1). From north to south, the Main Central Thrust fault (MCT), the Main Boundary Thrust fault (MBT) and the Main Frontal Thrust fault (MFT) are thought to be activated following a forward propagation sequence [e.g., Gansser, 1964; Le Fort, 1975]. At present, deformation is chiefly accommodated by thrusting along a major thrust 
fault, the Main Himalayan thrust (MHT) that connects the MFT to a subhorizontal shear zone below the high range and southern Tibet [e.g., Lavé and Avouac, 2000, 2001]. The MCT marks the contact between the High Himalayan crystalline units (HHC) and the Lesser Himalaya (LH). This major broad shear zone is thought to have been active approximately from $22 \mathrm{Ma}$ [Coleman and Hodges, 1998; Hodges et al., 1996] to 4-8 Ma [Catlos et al., 2001; Harrison et al., 1997]. On the basis of geomorphic criterion, namely the steepness of the front of the high range and river knickpoints, and evidence for brittle deformation posterior to the ductile fabric, some authors have suggested it might even be still active at places [e.g., Hodges et al., 2004].

[5] The deep structure of the crust beneath the High Himalaya has been investigated via reflection seismologic experiments [Alsdorf et al., 1998; Hauck et al., 1998; Makovsky et al., 1996], gravimetry [Cattin et al., 2001; Lyon-Caen and Molnar, 1985], magnetotelluric sounding [Lemonnier et al., 1999], and through seismic reflection and oil well $\operatorname{logs}$ in the most frontal parts of the system [Powers et al., 1998]. Together with the surface geology investigations and balanced cross-section modeling [DeCelles et al., 2001; Pêcher, 1989; Schelling and Arita, 1991], these data suggest that the major thrust faults splay from the MHT, the main feature separating the Himalayan orogenic wedge from the underthrusting Indian plate (Figure 1b). The MFT bounds to the south the fold-andthrust belt that forms the Siwalik hills along the piedmont. The MBT marks the contact between the Tertiary Siwalik molasses and the LH. Surface geology and well data in central Nepal suggest that the MFT, the MBT and the thrust faults located in between all root into a decollement. This decollement dips northward by $\sim 2.5 \%$ at a depth between 5 and $7 \mathrm{~km}$ [Lavé and Avouac, 2000] and extends to the north below the LH. North of the MBT, the LH is composed mainly of Proterozoic metasediments of Indian affinity [e.g., DeCelles et al., 2001; Robinson et al., 2001].

[6] The MCT lies approximately along the front of the high range, about $80 \mathrm{~km}$ north of the MBT. It dips steeply to the north, by $\sim 30^{\circ}$ beneath the HHC units, mainly formed of paragneiss and micaschists. Between the MBT and the MCT, klippes preserved within synforms are remnants of crystalline thrust sheets that are interpreted to root either into or beneath the MCT [e.g., DeCelles et al., 2001; Upreti and Le Fort, 1999]. These klippes include the Kathmandu klippe in central Nepal, the Jajarkot klippe in west central Nepal, and the Dadeldhura klippe in western Nepal, or Almora klippe, in Kumaon, India [DeCelles et al., 2001; Srivastava and Mitra, 1996; Stöcklin, 1980] (Figure 1a). These thrust sheets were probably emplaced prior to $\sim 20 \mathrm{Ma}$ as indicated from structural relationships [e.g., [DeCelles et al., 2001; Srivastava and Mitra, 1996] but also from the ages of detrital muscovites of probably HHC provenance of foreland deposits in the Dumri formation [DeCelles et al., 2001]. Subsequently, the thrust sheets were exhumed due to development of a broad antiform within the Lesser
Himalaya, the Pokhara-Gorkha anticlinorium [Pêcher, 1989], that cropped out to the surface between 5 and $11 \mathrm{Ma}$, as indicated from various geochemical indicators of sediment provenance sampled in the Siwaliks [DeCelles et al., 2000; Huyghe et al., 2001; Meigs et al., 1995; Najman and Garzanti, 2000; Parrish and Hodges, 1996; Robinson et al., 2001]. This structure has been interpreted as a hinterland dipping duplex [Brunel, 1986] and has been recognized on all sections across the Himalayas in Nepal. Some relatively detailed structural models of the duplex geometry have been derived from balancing crustal-scale sections [DeCelles et al., 2001; Schelling and Arita, 1991]. The schists and phyllites of the LH show a well-developed foliation and abundant microscale and mesoscale folding, attesting to significant deformation by pure shear, a mechanism inconsistent with the geometric rules used to balance a cross section. The details of these geometric and kinematic models may therefore be questioned, but we believe the broad-scale structural geometry must imply some sort of duplex structure as depicted in the section across west central Nepal (Figure 1b). Some lateral (E-W) variations in the geometry and degree of development of this duplex are suggested from the lateral succession of HHC klippes and LH windows (Figures 1a and 2).

\subsection{Stratigraphy of the Lesser Himalaya}

[7] Earlier investigators of this $\sim 300 \mathrm{~km}$ long stretch of the LH of Central and western Nepal defined a variety of stratotypes depending on their field area [Arita et al., 1973; Colchen et al., 1980; Fuchs and Frank, 1970; Hagen, 1969; Sakai, 1983; Stöcklin, 1980]. Here, we use the nomenclature that was unified by [Upreti, 1999] (Table 1). This nomenclature is based mainly on stratotypes from the districts around Kathmandu.

[8] The base of the Kuncha formation consists of alternated sandstones and gresophyllitic beds characteristic of turbiditic flysch deposits [Bordet, 1961]. Its upper northernmost part includes lenticular bodies of augen gneiss (the Ulleri augen gneisses) and amphibolitic layers of metabasic origin. These volcanosedimentary series marks the transition to the Fagfog formation which consist mainly of orthoquartzites with some sparse green phyllitic layers [Arita et al., 1973]. The overlying Dandagaon dark phyllites presents calcareous horizons [Arita et al., 1973] and are considered as equivalents of Heklang [Sakai, 1983] and Harichour phyllites [Sharma et al., 1984]. Above it, the Nourpul formation (Bajadi phyllites [Sakai, 1983], variegated formation [Sharma et al., 1984]) shows often colorful phyllitoquartzitic layers with episodic dolomitic layers. The Nourpul formation is often found at the bottom of parautochthonous thrust sheets within the Lesser Himalayan (e.g., at the base of the Palpa klippe). The overlying blue-gray calcariferous Dhading dolomites [Arita et al., 1973] are separated from Benighat black schists (Ramdighat slates [Sakai, 1983], Hatiya [Sharma et al., 1984], Simla slates [Fuchs and Frank, 1970]) by an erosional unconformity [Stöcklin, 1980]. This CM-bearing carbon-rich formation consists of 


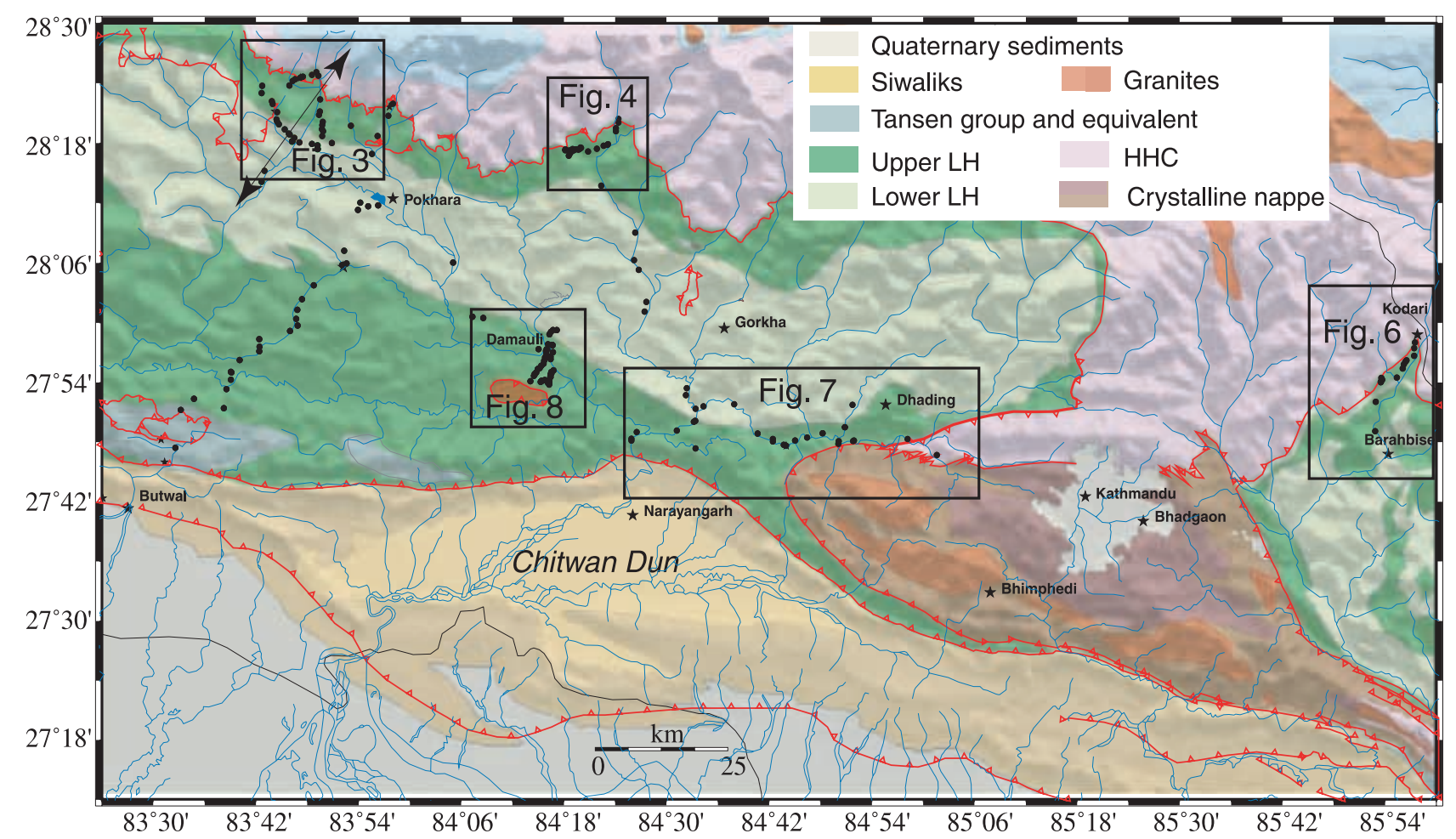

Figure 2. Geological map of study area, with locations of sampling sites. Boxes show locations area of Figures 3 (MCT Gorepani), 4 (MCT Marsyangdi), 6 (MCT Kodari), 7 (Kathmandu klippe), and 8 (Damauli klippe).

calcareous beds (Jhiku) and block conglomerates with a calcareous matrix. On the basis of their similar facies, the Benighat schists might be identified with the Barpak graphitic schists [Pêcher, 1978] which are found near the MCT zone in association with carbonates and garnet-kyanite-chlorite schists. The Malekhu and Robang formations are, respectively, dolomitic to calcareous and sericite-chlorite rich phyllites with quartzitic layers associated with metabasites and form the upper part of the LH under the Kathmandu klippe. These series are generally described as parts of the Nawakot complex (or Nawakot series of [Hagen, 1969]). We avoid this terminology that has been used with some variability by different authors, who defined it as a group, a series, a formation, or a complex [DeCelles et al., 2001; Sharma et al., 1984; Stöcklin, 1980; Upreti and Le Fort, 1999].

\section{Methods: Structural Measurements, Thermometry, and Thermochronology}

[9] We have compiled thermometric and thermochronologic data available in the literature for central Nepal and complement these data with new thermometric data obtained from RSCM data [Beyssac et al., 2004] and

Table 1. Simplified Stratigraphic Column for the Lesser Himalaya

\begin{tabular}{lll}
\hline \multicolumn{1}{c}{ Units } & \multicolumn{1}{c}{ Age $^{\mathrm{a}}$} & \multicolumn{1}{c}{ Central Nepal $^{\mathrm{b}}$} \\
\hline Tertiary & Miocene & Dumri \\
Tertiary & Eocene & Bhainskati \\
Gondwanian & Permian to Cretaceous (+Paleocene) & Gondwanas \\
Upper LH & & Robang \\
& & Malekhu \\
Upper LH & & Benighat \\
Upper LH & & Dhading \\
Lower LH & Middle Proterozoic & Nourpul \\
Lower LH & & Dandagaon \\
Lower LH & Eoproterozoic & Fagfog \\
\hline
\end{tabular}

${ }^{\text {a }}$ See, e.g., DeCelles et al. [2001].

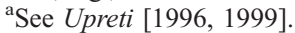


bring all of these into a common structural frame based on our own field observations and structural measurements. These data are available as auxiliary material ${ }^{1}$.

\subsection{Referencing the Sampling Points to a Common Structural Reference Frame}

[10] Since we are primarily interested in determining metamorphic gradients, a key issue in this study is the definition of a common structural framework to reference all the samples. Therefore we have paid particular attention to constrain the structural position of each sample from relatively dense structural measurements conducted along all the investigated transects. We measured elevation at each geographic location using a hand-held GPS and an altimeter calibrated on recent $1 / 25000$ topographic maps. Given that the structure is not perfectly bidimensional and that the samples do not lie along the same section, we had to define a common structural reference level to refer all the data to a single section. While the MCT would seem to be the most obvious structural reference, being recognized and mapped since the early 30's [Auden, 1935, 1937; Heim and Gansser, 1939], it presents complexities in the field that make it sometimes difficult to map precisely [Brunel, 1983]. Depending on the section, it appears to be a well defined fault zone (e.g., in Garhwal [Hodges and Silverberg, 1988; Metcalfe, 1993]), or a broad distributed shear zone (e.g., in the Everest region [Hubbard, 1989]). Actually, the distribution of strain within the shear zone is heterogeneous and difficult to quantify. It generally shows a number of ultramylonitic zones that can be recognized from detailed microstructural observations such as quartz $c$ axis [Bouchez and Pêcher, 1976; Kawamitsu and Hayashi, 1991]. In addition, several thrust shear zones have been reported within the $\mathrm{HHC}$ in Langtang [Reddy et al., 1993] and Modi Khola [Hodges et al., 1996] that might need to be distinguished from the MCT zone. As emphasized by [Searle et al., 2002], some authors have often mapped the MCT using nontectonic criteria such as petrology, lithology or geochemistry. Although these criteria might indeed be of tectonic significance, using them to define the position of the MCT might bias any attempt to assess lateral variations of the system.

[11] In fact, the lithological consistency between the HHC series along strike, in spite of the lateral variations in thickness, [e.g., Le Fort, 1975], argue for its structural integrity. This is also suggested from the clearly different LH and HHC protoliths indicated by neodymium isotopes (about $-22 \varepsilon_{\mathrm{Nd}}$ for LH and about $-15 \varepsilon_{\mathrm{Nd}}$ for HHC) [Ahmad et al., 2000; Huyghe et al., 2001; Robinson et al., 2001; Whittington et al., 1999]. Thus the thrust fault contact must lay between the paragneisses (HHC) and the black slates and quartzites (LH), lending support to the validity of defining the MCT based on lithology.

\footnotetext{
${ }^{1}$ Auxiliary material is available at ftp://ftp.agu.org/apend/tc/
} 2003 TC001564.
[12] We have first mapped the MCT based on our own structural and lithological observations. Published maps [e.g., Colchen et al., 1986] were also taken into account with consideration of how the MCT was identified in the field by the authors.

\subsection{Thermometric Methods}

[13] Lithology in the LH is generally not appropriate for conventional thermometric studies since the index mineral assemblages relevant to conventional thermobarometric analysis are only found adjacent to the MCT zone where the upper units have experienced relatively high temperatures. We therefore present only a few thermometric estimates based on Fe:Mg exchange between garnet $(\mathrm{Gt})$ and biotite (Bi) [Ferry and Spear, 1978]. Measuring garnet rims and cores with associated biotites allows then to estimate temperature during garnet growth assuming that those minerals are in equilibrium. Analyses were performed using Cameca Camebax and SX50 microprobes (Camparis, Paris).

[14] The carbonaceous black schists, which are rich in CM and relatively abundant in the $\mathrm{LH}$, make it possible to use an alternative and complementary approach based on the degree of graphitization of the CM. We used the geothermometer based on Raman spectroscopy of carbonaceous material (RSCM), that was recently calibrated in the range between $330^{\circ} \mathrm{C}$ and $650^{\circ} \mathrm{C}$ [Beyssac et al., 2002]. This technique provides a measurement of the peak metamorphic temperatures which seems insensitive to retrogression during the retrograde part of the $\mathrm{P}-\mathrm{T}$ path. It therefore appeared to us as a powerful technique to be applied in the LH providing the possibility for a relatively dense sampling because of its simplicity. Altogether, 58 samples from central Nepal were processed. The details of these RSCM analysis and the uncertainties on the determination of the peak temperatures are presented and discussed by Beyssac et al. [2004].

\subsection{Thermochronology}

[15] We complemented RSCM thermometry using thermochronology from ${ }^{40} \mathrm{Ar} /{ }^{39} \mathrm{Ar}$ measurements on muscovites. High-purity concentrates of muscovite grains were separated from 20 rocks collected along the Marsyangdi river and the Damauli klippe. They were analyzed with a VG3600 automated mass spectrometer (UCLA) using the ${ }^{40} \mathrm{Ar} /{ }^{39} \mathrm{Ar}$ method following irradiation in the Ford reactor (University of Michigan) for Marsyangdi and the McMaster reactor for Damauli samples. Typically, about $5 \mathrm{mg}$ of muscovite was step-heated within a double vacuum furnace. Details about the analytical procedure are given by McDougall and Harrison [1999]. The ${ }^{40} \mathrm{Ar} /{ }^{39} \mathrm{Ar}$ release spectra, inverse isotope correlation diagrams, and technical specifications are detailed in the auxiliary material; the interpreted ages are listed in Table 2.

\section{Thermometric and Chronological Constraints}

[16] In this section we consider various key area and present thermometric and geochronologic results deter- 
Table 2. Sample Location and Thermochronologic Data

\begin{tabular}{|c|c|c|c|c|c|c|c|c|}
\hline Sample & Longitude & Latitude & TGA & $1 \mathrm{SD}$ & WMA & $1 \mathrm{SE}$ & IIA & $1 \mathrm{SD}$ \\
\hline MA86 & 84.385 & 28.236 & 10.9 & 0.3 & 9.3 & 1.7 & 3.7 & 3.8 \\
\hline MA67 & 84.339 & 28.240 & 7.2 & 0.3 & 6.9 & 1.4 & 4.3 & 1.9 \\
\hline MA77 & 84.375 & 28.241 & 6.0 & 0.2 & 5.5 & 0.3 & 5.1 & 0.4 \\
\hline MA69 & 84.359 & 28.243 & 6.1 & 0.2 & 5.6 & 0.4 & 4.6 & 0.7 \\
\hline MA74 & 84.374 & 28.244 & 8.7 & 0.2 & 7.7 & 0.8 & 5.8 & 1.0 \\
\hline MA65 & 84.338 & 28.245 & 6.6 & 0.2 & 5.7 & 0.7 & 3.7 & 0.9 \\
\hline MA64 & 84.333 & 28.248 & 5.5 & 0.2 & 5.1 & 0.4 & 4.4 & 0.3 \\
\hline MA63 & 84.334 & 28.250 & 4.1 & 0.2 & 3.9 & 0.2 & 3.6 & 0.4 \\
\hline MA62 & 84.335 & 27.253 & 5.6 & 0.2 & 5.2 & 0.1 & 4.9 & 0.2 \\
\hline MA61 & 84.339 & 27.254 & 13.9 & 0.3 & 10.0 & 1.0 & 3.9 & 4.1 \\
\hline MA60 & 84.355 & 28.261 & 6.1 & 0.4 & 6.3 & 0.4 & 5.4 & 0.5 \\
\hline MA59 & 84.360 & 28.263 & 4.4 & 0.2 & 4.3 & 0.4 & 4.1 & 0.4 \\
\hline MA81 & 84.336 & 28.329 & 2.4 & 0.8 & 2.4 & 0.1 & 2.4 & 0.1 \\
\hline MA81bk & & & 19.1 & 0.2 & 18.9 & 0.4 & 18.0 & 0.9 \\
\hline MA88 & & & 47.3 & 2.2 & 29.1 & 5.0 & 738 & 2596 \\
\hline D0113 & 84.269 & 27.900 & 22.0 & 0.5 & 15.6 & 2.3 & 10.9 & 5.0 \\
\hline D0124 & 84.247 & 27.917 & 21.4 & 0.2 & 18.4 & 1.5 & 14.9 & 3.1 \\
\hline D0121 & 84.242 & 27.911 & 26.9 & 0.5 & 22.4 & 1.4 & 20.1 & 1.1 \\
\hline D0107 & 84.274 & 27.914 & 67.3 & 1.4 & 31.3 & 10.2 & 13.3 & 37.7 \\
\hline D0119 & 84.255 & 27.901 & 26.3 & 0.3 & 23.8 & 1.3 & 22.2 & 1.6 \\
\hline
\end{tabular}

${ }^{\mathrm{a}} \mathrm{The}{ }^{40} \mathrm{Ar} /{ }^{39} \mathrm{Ar}$ release spectra, inverse isotope correlation diagrams, and technical specifications are available as auxiliary material. The $J$ factor, determined from Fish Canyon sanidine $(27.8 \mathrm{Ma})$, is at $(61.1 \pm 0.1) 10^{-4}$ for the Marsyangdi samples and $(35.5 \pm 0.1) 10^{-4}$ for Damauli samples. Abbreviations are as follows: TGA, total gas age; WMA, weighted mean age; IIA, inverse isochrone age; 1SD, standard deviation.

mined here as well as data compiled from the literature. We have tried to bring these data into a common structural frame based on our own field observations.

\subsection{Near the MCT Zone at the Front of the High Range}

[17] Three areas were selected along the MCT zone: Gorepani, Margsyandi, and Kodari area. The present thickness of the overlaying HHC differs in the three areas from around $5 \mathrm{~km}$ (Gorepani) to around $10 \mathrm{~km}$ (Kodari), offering an opportunity to test whether these variations might be correlated with lateral variations of thermal metamorphism.

\subsubsection{Gorepani Area: Along the Annapurna Range} From Kali Gandaki to Seti

[18] In this area, the HHC sheet is thin, about $5 \mathrm{~km}$, and overlies the LH units along a relatively well defined MCT shear zone, locally known as the Chomrong thrust (Figure 3a). This area has already been the focus of a number of studies that have documented its lithostratigraphy [e.g., Arita, 1983; Colchen et al., 1980; Ohta et al., 1973], petrology [Le Fort, 1986; Pêcher, 1975, 1977, 1978, 1989; Hodges et al., 1996; Kaneko, 1995; Vannay and Hodges, 1996] and microstructures [Bouchez and Pêcher, 1976, 1981; Kawamitsu and Hayashi, 1991; Pêcher et al., 1991]. Several other shear zones affect the upper part of the $\mathrm{LH}$, among them the Lumle thrust and the Birethanti (or Chandrakot) thrust are the most prominent ones (Figure 3a).

[19] Five samples of carbonaceous slates were collected $\sim 500$ to $1500 \mathrm{~m}$ below the MCT on three adjacent transects along the Gorepani, Modi and Seti rivers (Figure 3b). They yielded RSCM temperatures, between $510^{\circ}$ and $550^{\circ} \mathrm{C}$ [Beyssac et al., 2004] and no significant trend between temperature and sample position is observed in this set. Garnet/Biotite (Gt/Bi) thermometric estimates on four samples collected at structural positions a few hundreds meters above and below the carbonaceous slates provided respectively higher temperatures $\left(540^{\circ} \mathrm{C} \mathrm{Gt} \mathrm{rim}\right.$ and $690^{\circ} \mathrm{C}$ Gt core in the $\mathrm{HHC})$ and lower temperatures $\left(400^{\circ} \mathrm{C} \mathrm{Gt}\right.$ core and $475^{\circ} \mathrm{C}$ Gt rim, than RSCM temperatures. Altogether these results are consistent with a general inverted thermal gradient.

[20] Both the conventional thermometric estimates obtained here and the RSCM data are in good agreement with previous thermometric estimates from $\mathrm{Gt} / \mathrm{Bi}$ temperatures above and below these outcrops [Kaneko, 1995; Le Fort et al., 1986]. These data show a peak metamorphic temperature that decreases down section, with a relatively abrupt discontinuity near the MCT accompanied by a transition from garnets growing during heating to garnets growing during cooling (Figure $3 \mathrm{~b}$ ). By contrast, the fault zones within the LH are not associated with any identifiable discontinuities.

[21] $\mathrm{Gt} / \mathrm{Bi}$ estimates obtained in the lower part of the $\mathrm{LH}$, corresponding to positions below the first LH sliver in the MCT zone, are generally lower than $500^{\circ} \mathrm{C}$. At such temperature $\mathrm{Bi}$ and $\mathrm{Gt}$ are probably not at thermodynamic equilibrium [Ferry and Spear, 1978; Holdaway et al., 1997]. The validity of these determinations is therefore questionable although we have plotted them in Figure $3 \mathrm{~b}$ for information.

\subsubsection{Around the Marsyangdi River}

[22] In the area south of the Manaslu igneous complex, the $\mathrm{HHC}$ is $\sim 8 \mathrm{~km}$ thick and the MCT lies locally about $25 \mathrm{~km}$ farther to the north than along the adjacent westward and eastward segments, defining a sort of embayment in map view (Figure 2). Like in the Gorepani area, some secondary shear zones affect the upper portion of the LH, the most prominent one being the MCT-1 as defined by [Catlos et al., 2001] (Figure 4a). Thermobarometrical results from conventional petrology in this area are already 


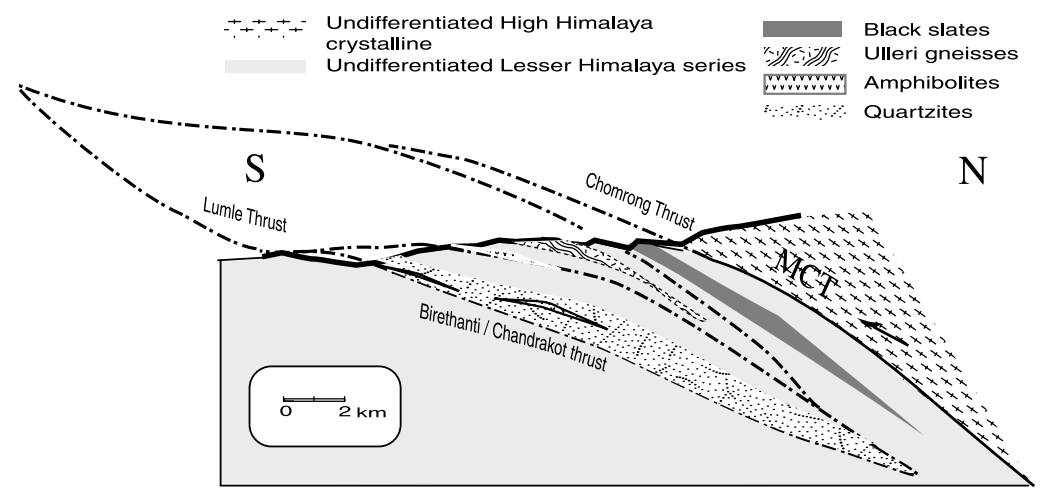

a

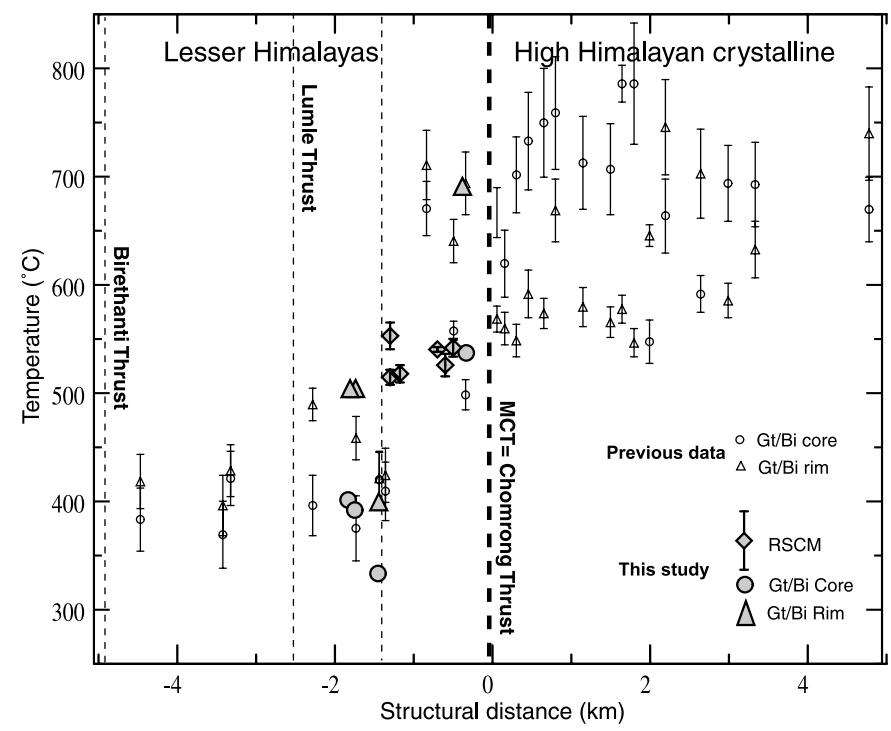

b

Figure 3. (a) Simplified section across the MCT in Gorepani area (along the Seti river). (b) Temperatures (with $1 \sigma$ uncertainties) versus structural distance to the MCT determined from RSCM [Beyssac et al., 2004] and from Gt/Bi thermometry on garnet cores and rims [this study; Kaneko, 1995; Le Fort et al., 1986]. Many $\mathrm{Gt} / \mathrm{Bi}$ temperatures in the $\mathrm{LH}$ are lower than $500^{\circ} \mathrm{C}$, thus out of the domain of validity of the technique and are therefore questionable.

available [Catlos et al., 2001]. Black schists crop out in a carbonaceous unit found within a $1 \mathrm{~km}$ thick unit that appears to be in a similar structural position as the black slates in the Gorepani area (Figures $4 \mathrm{a}$ and $4 \mathrm{~b}$ ). Peak metamorphic temperatures were measured from 11 samples and yielded well- clustered temperatures ranging from $520^{\circ} \mathrm{C}$ to $550^{\circ}$ [Beyssac et al., 2004]. These temperatures are consistent with previous estimates determined from mineral assemblages [Catlos et al., 2001] (Figure 4b). All these temperatures indicate an apparent inverted thermal gradient higher than $20^{\circ} \mathrm{C} / \mathrm{km}$. So as in the Gorepani area, peak metamorphic temperatures decrease down section across the MCT, with a relatively abrupt gradient close to the shear zone. By contrast, there is no significant change of thermobarometric conditions across the MCT-1.
[23] In Figure 5, we have reported new Ar/Ar ages on muscovites from sixteen samples collected along the Marsyangdi river together with cooling ages from samples collected at the base of the High Himalaya Crystalline in the same area [Edwards, 1995] and along an adjacent section in the Darondi Khola [Catlos et al., 2001]. These ages span a wide range of values between 2.5 and $20 \mathrm{Ma}$. When these data are projected on the same section, they depict a minimum cooling age around $2.5 \mathrm{Ma}, 0$ to $3 \mathrm{~km}$ below the MCT, and increase gradually north and south of the MCT.

\subsubsection{Kodari Area}

[24] This area lies along the edge of the Okhaldunga large window east to the Kathmandu klippe. The HHC presents here a section $\sim 10 \mathrm{~km}$ thick over the LH. We have sampled 
a
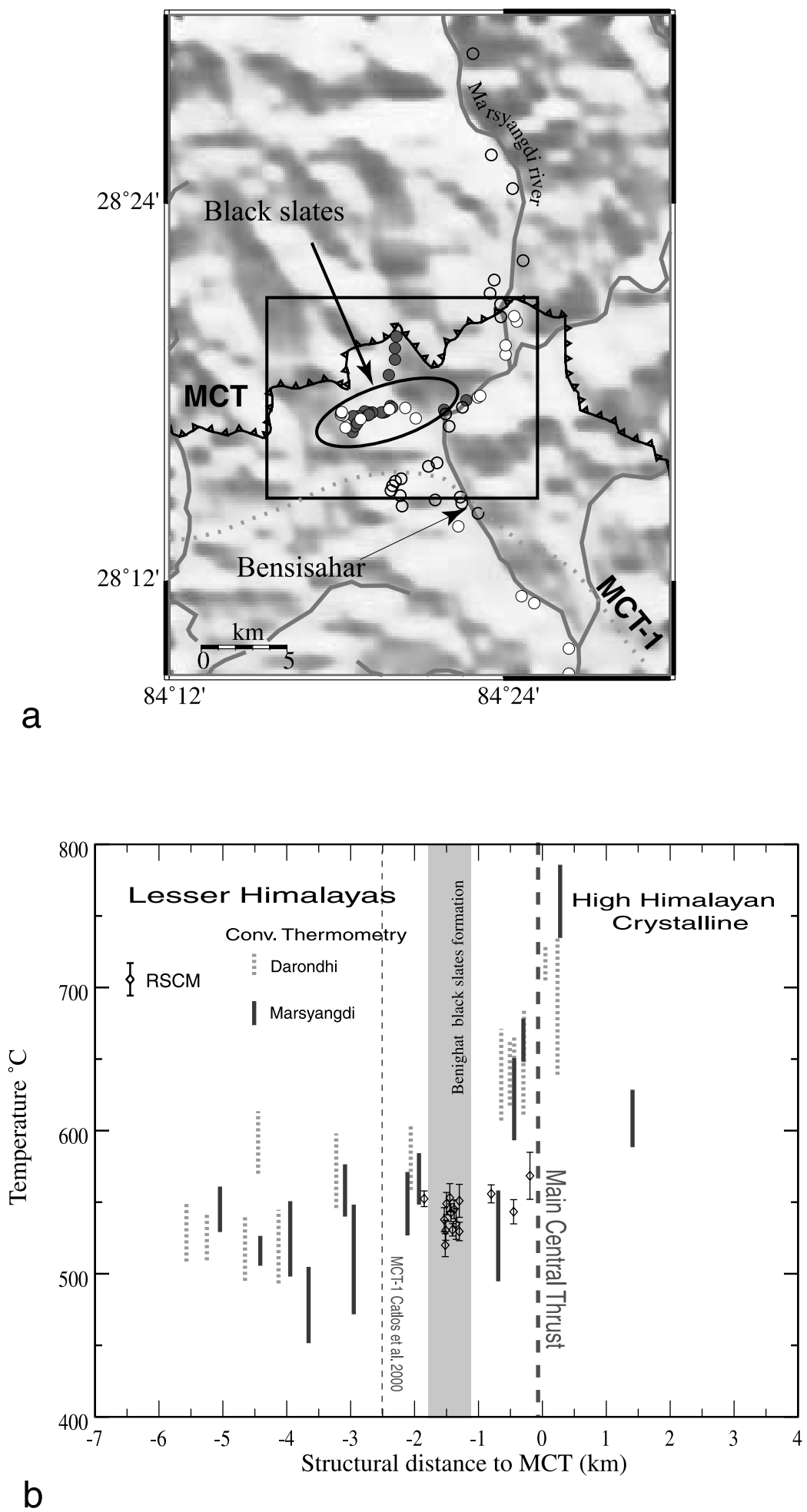

Figure 4. (a) Location of the samples used for thermometry along Marsyangdi river. MCT from Colchen et al. [1986]. Solid gray circles show location of samples used for RSCM thermometry [Beyssac et al., 2004]; open circles show location of samples for conventional thermobarometry [Catlos et al., 2001] and thermochronology. (b) Peak metamorphic temperature (with $1 \sigma$ uncertainties) versus structural distance to the MCT (diamonds with thin bars, $1 \sigma$ uncertainties). Also reported are temperatures from Catlos et al. [2001] along the Marsyangdi (bold bars) and the Darondi Khola (dotted bars). 


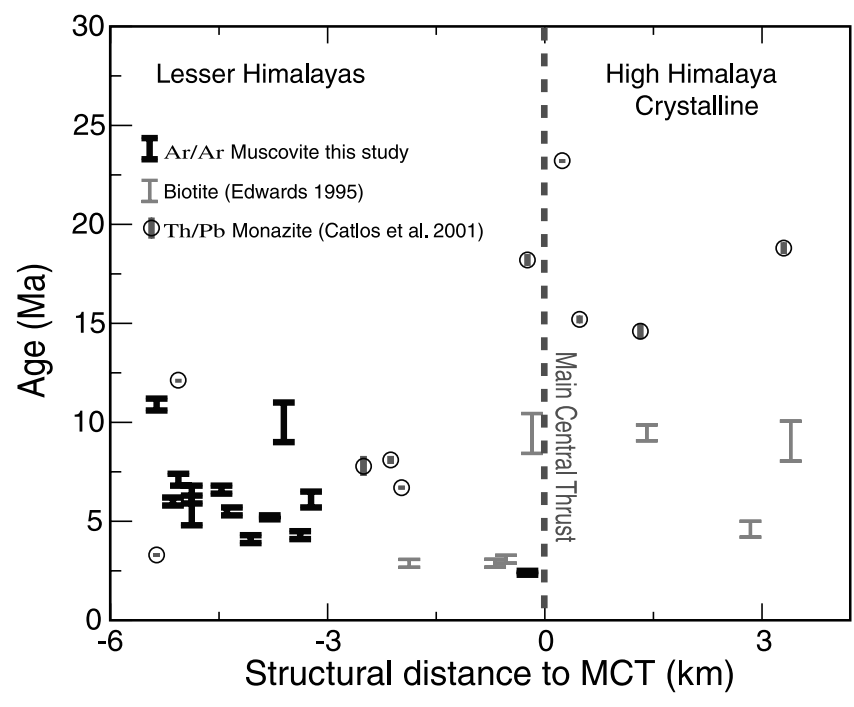

Figure 5. Plot of thermometric ages and elevation of samples, from this study and previous investigations by Edwards [1995] and Catlos et al. [2001], as a function of the structural distance in the Marsyangdi area. The section strikes $\mathrm{N} 018^{\circ} \mathrm{E}$.

along a 10 kilometers long reach of the Barhabise-Kodari (Figure 2) road. This cross section corresponds to a structural thickness of about $2 \mathrm{~km}$. Most samples were collected from a narrow zone where carbonaceous slates form high cliffs. The RSCM temperatures range between $515^{\circ}$ and $570^{\circ} \mathrm{C}$ [Beyssac et al., 2004], decreasing down the structural section. These temperatures complete consistently the thermobarometric data of [Rolfo et al., 2001]. This data suggests an inverted gradient locally between $25^{\circ}$ and $50^{\circ} \mathrm{C} / \mathrm{km}$ on average along this section across the MCT (Figure 6).

\subsection{LH Below the Crystalline Nappes}

[25] In complement to the sites located along the front of the high range, we also investigated sections across the $\mathrm{LH}$ farther to the south, below the Kathmandu and the Damauli klippes.

\subsubsection{Under the Kathmandu Klippe}

[26] This area along the southwestern edge of the Kathmandu klippe has been extensively studied (Figure 7). Hagen [1969] and Hagen and Hunger [1952] proposed a structural interpretation involving a number of different nappes forming the Nawakot and Kathmandu complexes. This early view was simplified later on [Brunel, 1975; Stöcklin, 1980; Stöcklin and Bhattarai, 1977]. The main thrust fault at the base of the klippe is known as the Mahabarat thrust, which in some interpretations is considered to be the southern extension of the MCT. Thermobarometric estimates available from the literature indicate peak metamorphic temperatures decreasing between $600^{\circ}$ and $550^{\circ} \mathrm{C}$ from the core to the tips of the klippe [Johnson et al., 2001; Rai et al., 1998].

[27] Along the Trisuli river, LH units crop out for nearly $50 \mathrm{~km}$ with relatively abundant occurrence of black slates within the Dandagaon phyllitic formation and the upper
Benighat slates. The RSCM temperatures range in this area from less than $330^{\circ} \mathrm{C}$ up to $470^{\circ} \mathrm{C}$ [Beyssac et al., 2004]. Referencing all the points in the area to a single structural section is not straightforward due to the synclinal geometry and lateral variation of the various lithostratigraphic units (Figure 7b). For example the thickness of the Benighat Slates varies by a factor of two between $\sim 1.5$ and $3 \mathrm{~km}$, most probably due to tectonic shear. We have simply referenced the samples according to their lithostratigraphic position with account for lateral variations of stratigraphic thicknesses. This data indicates temperatures which decrease down the section with an inverted gradient locally as steep as $50^{\circ} \mathrm{C} / \mathrm{km}$ (Figure $7 \mathrm{c}$ ).

[28] Previous geochronological studies had largely documented the klippe itself and the underlying shear zone. We therefore found it unnecessary to complement this geochronological data set. They consist of Ar/Ar ages on muscovite and biotite [Arita and Ganzawa, 1997; Macfarlane et al., 1992; Rai, 1998; P. Copeland, personal communication, 2000] and fission track ages on apatite and zircon [Arita et al., 1997; P. Copeland, personal communication, 2000]. These data are discussed in the next section.

\subsubsection{Damauli Klippe}

[29] The upper units of the LH are well exposed in a large synclinorium west of the Kathmandu klippe. The axis of the synclinorium corresponds to the course of the Kali/Krishna Gandaki river. In this area, previously described by Ohta et al. [1973], a $\sim 2 \mathrm{~km}$ thick unit of black slates similar to the Benighat slates, is underlain by units alike those within the Nourpul formation. The section above the black slates consists of dolomitic marbles, probably equivalents of the Malekhu formation, then phyllites with quartzitic levels (similar to those within the Robang formation but without any metabasitic level) and garnet-bearing micaschists. The upper portion of the Lesser Himalaya is intensely sheared as indicated from quartz-chlorite lenticular exudates, and asymmetrical microfolds showing a top-to-the-south sense

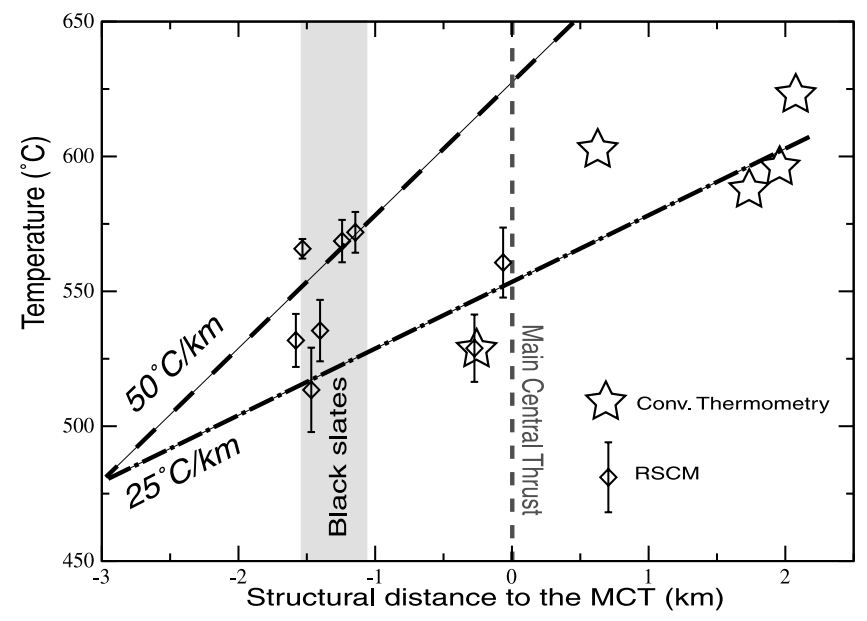

Figure 6. Peak metamorphic temperatures (with $1 \sigma$ uncertainties) determined from RSCM [Beyssac et al., 2004] on carbonaceous slates versus structural distance to the MCT and temperatures deduced from conventional thermobarometry [Rolfo et al., 2001]. 


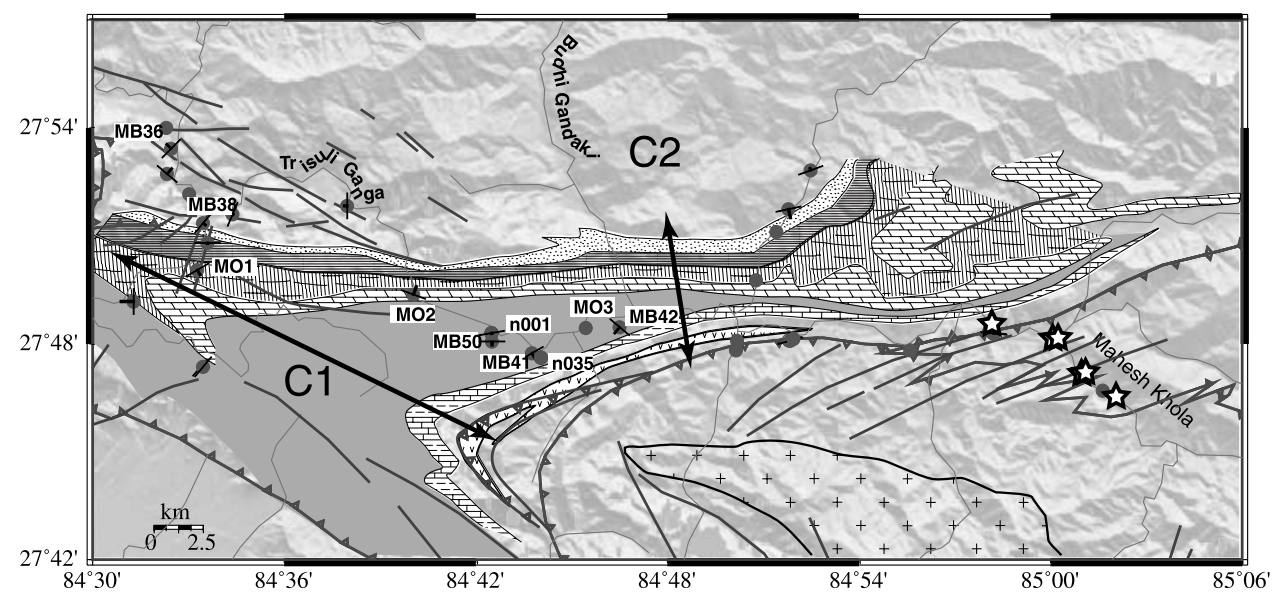

a

b
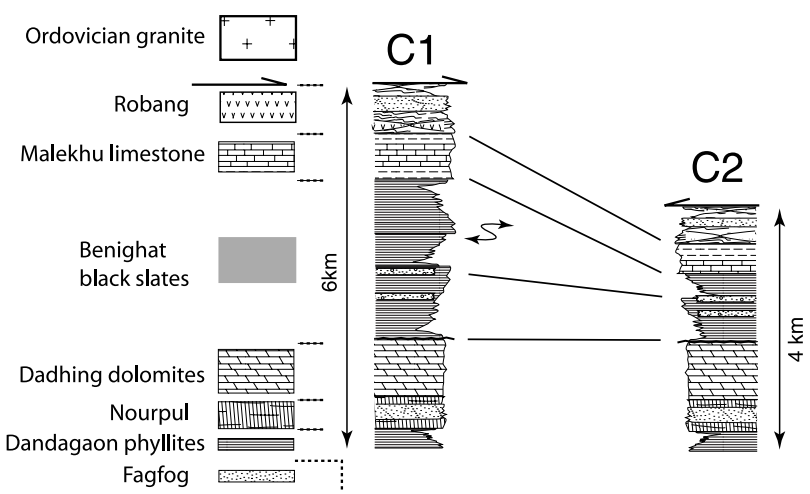

C

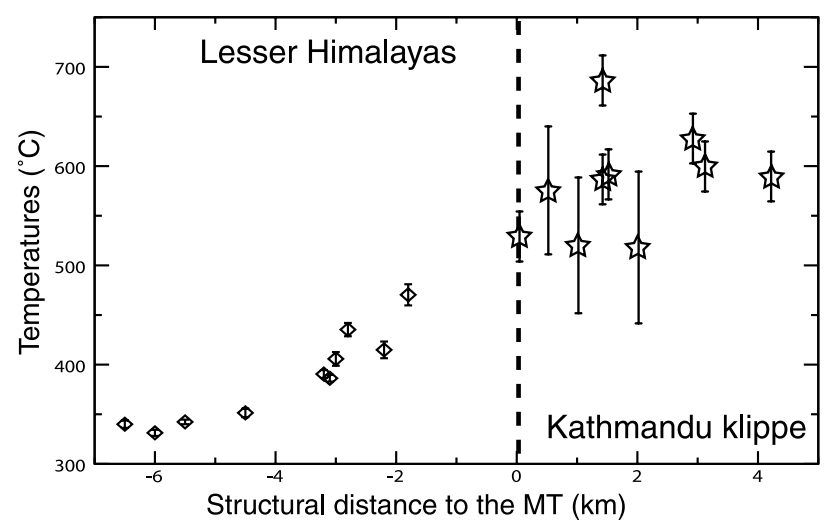

Figure 7. (a) Simplified geological map of the southwestern part of the Kathmandu klippe with samples locations. Circles mark locations this study; stars mark locations of Johnson et al. [2001] study. The lithology within the LH are from Stöcklin et al. [1980]. See box in Figure 2 for location. (b) Stratigraphy of Lesser Himalayan series under the Kathmandu klippe deduced from Stöcklin [1980] and Stöcklin et al. [1980]. (c) Plot of peak metamorphic temperatures [Beyssac et al., 2004] versus structural distance to the Mahabarat thrust fault (MT) which is the equivalent of the MCT below the Kathmandu klippe.

of shear. This section is very similar to the section along the western edge of the Kathmandu klippe. That tectonosedimentological setting suggests that the Damauli klippe is probably simply a remnant of a thrust sheet that used to extend from the Kathmandu klippe to the Jajarkot klippe (Figures 1a and 2).

[30] Thirteen carbonaceous samples were collected along two parallel sections (Figure 8a). The relatively monoclinal dip angles (mean strike $\mathrm{N} 120^{\circ} \mathrm{E}$, dip north by about $40^{\circ}$; Figures $8 \mathrm{a}$ and $8 \mathrm{~b}$ ) made it possible to reference all the points to a common $5 \mathrm{~km}$ thick structural section with relatively little uncertainty. D01-40, the lowermost sample, and D01-07, at the base of the phyllonitic outcrops, present respectively the lowest $\left(365^{\circ} \mathrm{C}\right)$ and highest $\left(525^{\circ} \mathrm{C}\right) \mathrm{RSCM}$ temperatures [Beyssac et al., 2004]. Between these two points, the peak metamorphic temperatures decrease grad- 


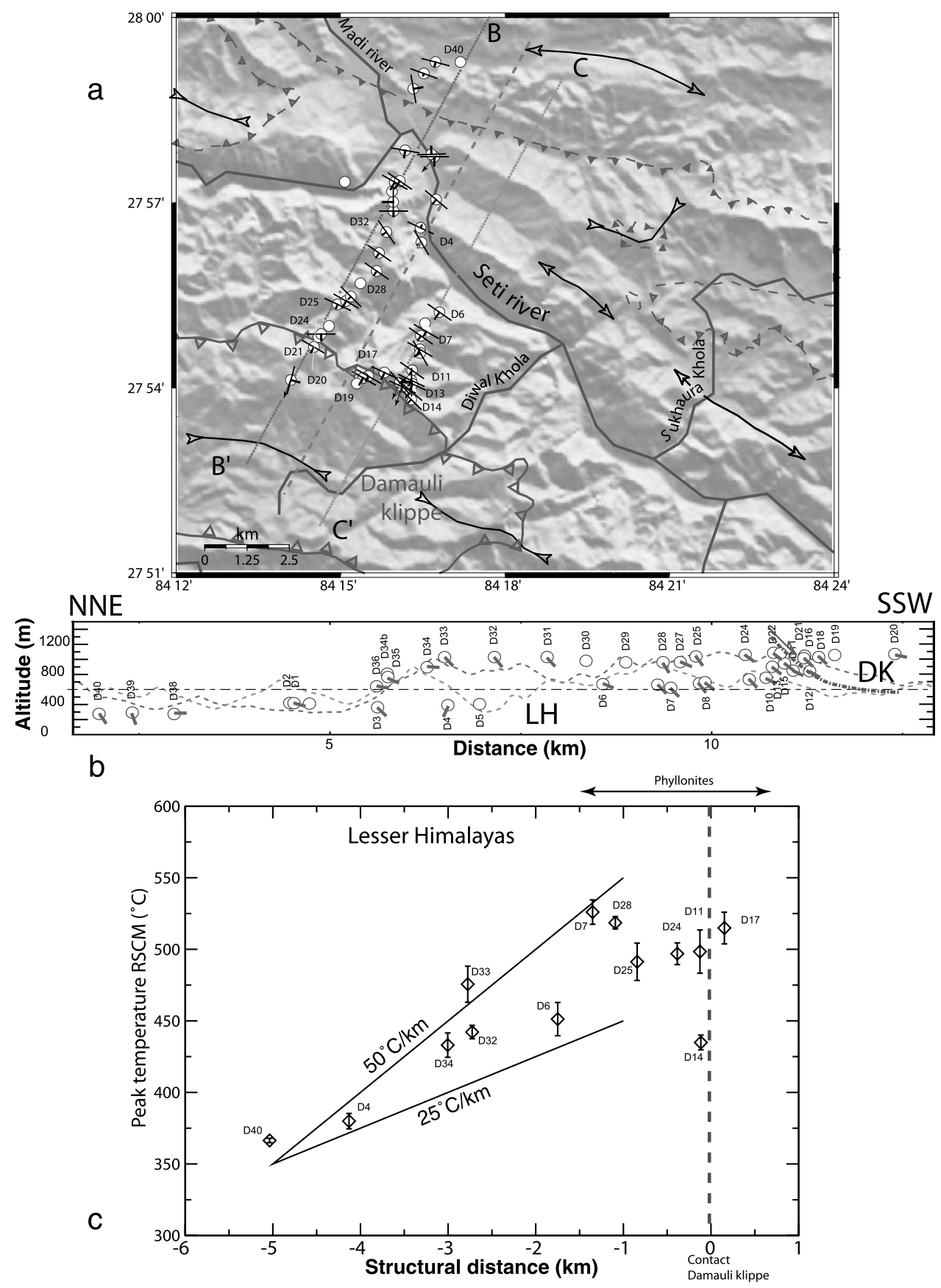

Figure 8. (a) Geological map of the Damauli area with samples locations. See box in Figure 2 for location. (b) $\mathrm{N} 028^{\circ}$ profiles with location of samples and dip angles along the two parallel ridges. Topography from SRTM30. (c) Plot of peak metamorphic temperature deduced from RSCM thermometry with $1 \sigma$ uncertainties [Beyssac et al., 2004] as a function of the structural distance to the Mahabarat thrust fault MT ( MCT), at base of the Damauli klippe.

ually down the section (Figure $8 \mathrm{c}$ ). It indicates an inverted gradient of the order of $30^{\circ}-40^{\circ} \mathrm{C} / \mathrm{km}$ on average along these sections. Within the phyllonites, the peak temperature is relatively uniform at around $500^{\circ} \mathrm{C}$ except for one outlier (D01-14 at $434^{\circ} \mathrm{C}$ ) (Figure 8c). Samples from the $\mathrm{LH}$ in the Damauli area yielded U-shaped spectra and isochron analysis suggests significant Ar inheritance. Nevertheless, these samples yielded average age of 15-25 Ma (total gas, weighted means and isochron ages) and sample D01-21 yielded a plateau age at $22 \mathrm{Ma}(80 \%$ Ar release).

[31] Dense sampling along two mainly monoclinal cross sections in this region led to a well-constrained thermal structure of the upper LH in the Damauli area. The decrease of peak temperatures with structural distance is similar to 

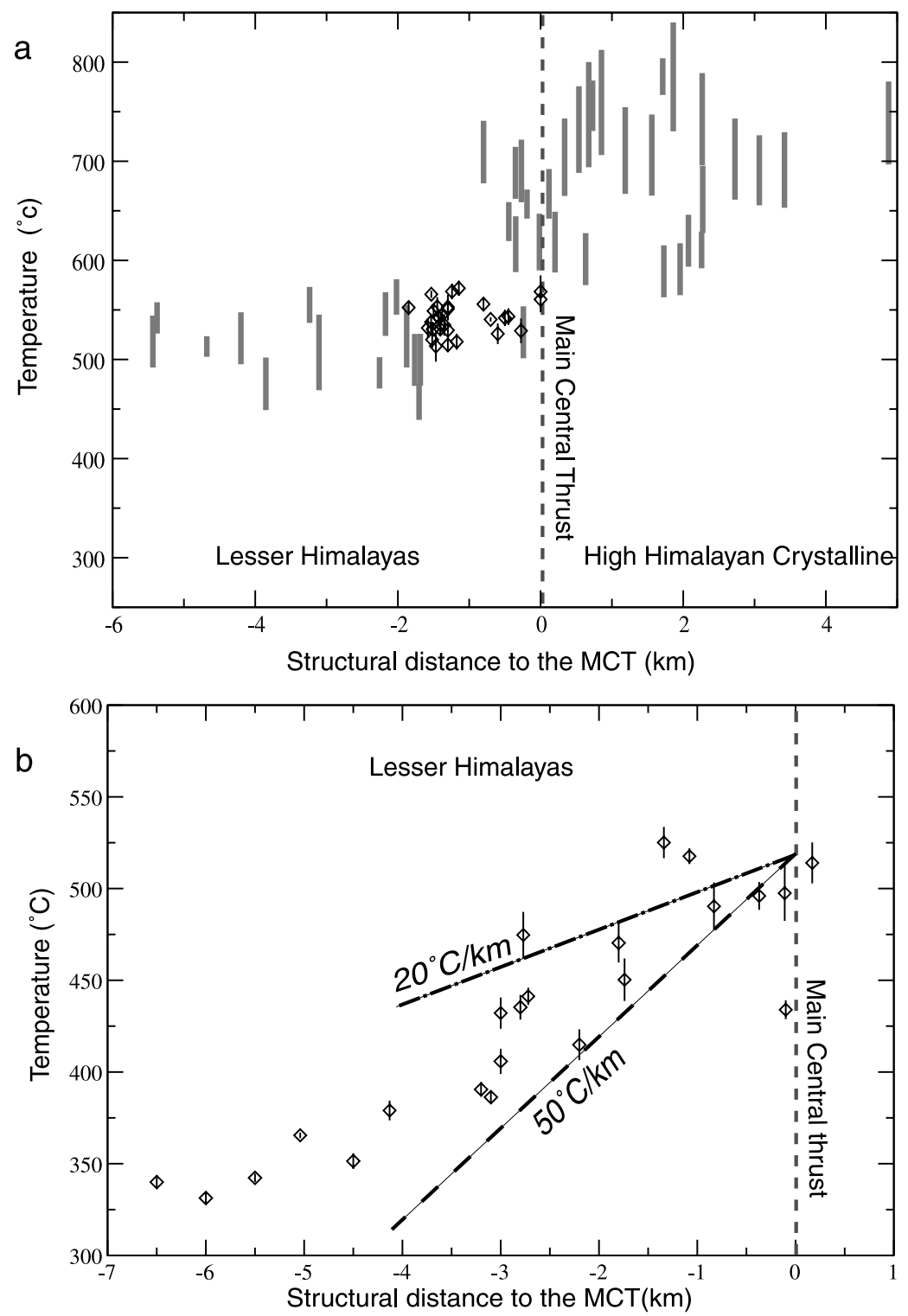

Figure 9. Peak metamorphic temperature as a function of structural distance to the MCT (a) near the MCT zone at the front of the high range (compiled from Figures 3, 4, and 6), i.e., about $80 \mathrm{~km}$ from the MBT, and (b) below the Kathmandu and Damauli klippes, about $50 \mathrm{~km}$ south of the MCT, i.e., $30 \mathrm{~km}$ from the MBT (compiled from Figures 7 and 8). Here we have omitted the values under $500^{\circ} \mathrm{C}$ obtained from $\mathrm{Gt} / \mathrm{Bi}$ thermometry since these results are out of the domain of validity of the technique.

that determined in the Kathmandu area, with a similar inverted gradient. The thermal fingerprint of the contact separating the upper LH from the klippe itself suggests that this contact is similar to the Mahabarat thrust.

\section{Discussion}

\subsection{Evidence for a Himalayan Inverted Thermal Gradient Across the LH}

[32] Peak metamorphic temperatures in the LH obtained along the front of the high range near the MCT, are found to fall all in a relatively narrow range of values $\left(\sim 500^{\circ}-\right.$ $570^{\circ} \mathrm{C}$ ) with a mean value $541^{\circ} \pm 16^{\circ} \mathrm{C}$ [Beyssac et al., 2004]. These temperatures seem to depict relatively similar gradients with structural distance to MCT when each area is considered separately. To emphasize the similarities, all the data were collapsed on a single structural section (Figure 9a). It shows that the upper units of the $\mathrm{LH}$, immediately below the MCT at the front of the high range, were brought to maximum temperatures around $540^{\circ} \mathrm{C}$, while temperatures increase upward across the MCT to about $700^{\circ} \mathrm{C}$ in the $\mathrm{HHC}$ a few kilometers above the MCT.

[33] Beneath the southern extension of the crystalline nappes, the LH units did not experience as high temperatures and reached a maximum slightly above $525^{\circ} \mathrm{C}$, in 


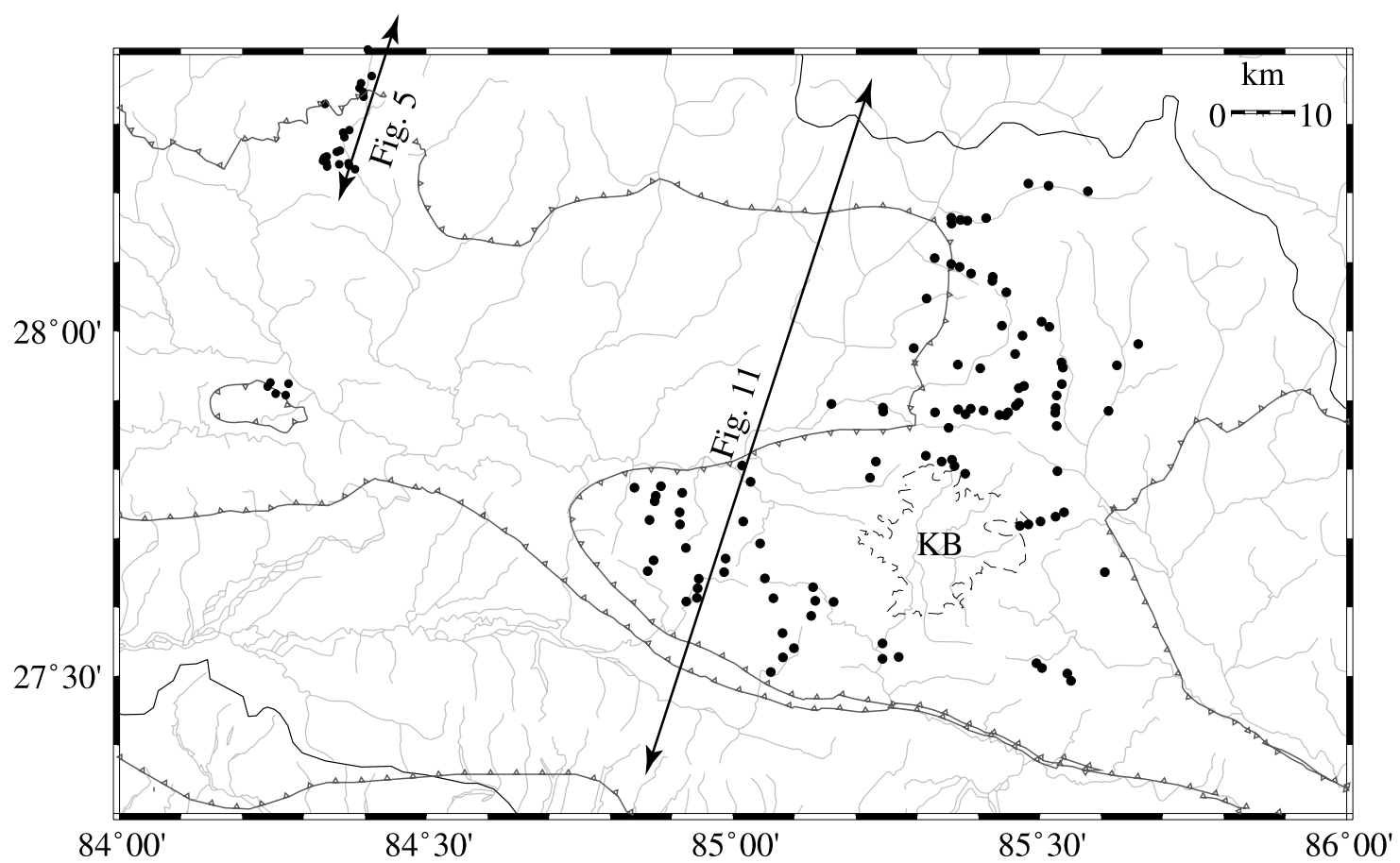

Figure 10. Structural map with location of samples processed for thermochronology with location of sections shown in Figures 5 and 11. We report our data together with data from previous studies by Edwards [1995], Catlos et al. [2001], Macfarlane et al. [1992], Arita et al. [1997], Arita and Ganzawa, 1997; and P. Copeland, personal communication, 2000].

continuity with those at the base of the crystalline thrust sheets (Figure 9b). The data collected below both the Damauli and the Kathmandu klippes define an inverted gradient between $20^{\circ} \mathrm{C} / \mathrm{km}$ and $50^{\circ} \mathrm{C} / \mathrm{km}$ across the $4 \mathrm{~km}$ uppermost section of the LH. Further down the section, temperatures decrease to less than $330^{\circ} \mathrm{C}$ (Figure 9b). Both the thermometric ages and the concordance of the pattern of peak metamorphic temperatures with the tectonic structure suggest that peak temperatures were reached during the Himalayan deformation phase and are not inherited from any older metamorphic event.

[34] In Figure 10, we have located all the geochronological data available from the literature and this study for both the Marsyangdi and Kathmandu area. Projected as a function of the distance to the MBT along a N018E section (Figure 11), these data reveal that ${ }^{40} \mathrm{Ar} /{ }^{39} \mathrm{Ar}$ muscovite ages increase southward by about $0.24 \mathrm{Myr} / \mathrm{km}$ on average. The scatter in this plot can be ascribed in part to the differences in samples elevation. Given the relatively large rates of exhumation in the area this term is probably smaller than about 1 Myr. More probably the variability comes from lateral variations (all data are plotted assuming a 2-D geometry), from the uncertainties on the cooling ages as well as from the presence of local younger ages probably due to retrograde fluid injections in the highly fractured shear zones.

[35] Given that the ${ }^{40} \mathrm{Ar} /{ }^{39} \mathrm{Ar}$ blocking temperature for muscovite is of the order of $350^{\circ} \mathrm{C}$, there is little doubt that the peak metamorphic temperatures in the $\mathrm{LH}$ were also attained over the last 20 Myr or so. The inverted metamor- phic gradient affecting the upper $5 \mathrm{~km}$ of the LH throughout the whole central Nepal must also have developed over the last about 20 Myr following the emplacement of the MCT and of the crystalline nappes that were thrusted over the Lesser Himalaya.

\subsection{Implications for the Structural Evolution of LH: Underplating and Shearing of $\mathrm{LH}$}

[36] The observed thermal gradient between $20^{\circ} \mathrm{C}$ and $50^{\circ} \mathrm{C}$ is remarkably steep. For comparison we have estimated the maximum inverted gradient predicted from various steady state thermal structures published in the literature [Cattin and Avouac, 2000; Henry et al., 1997; Royden, 1993]. None of these solutions do predict, at the $5 \mathrm{~km}$ scale of our observation, a gradient larger than about $10^{\circ} \mathrm{C} / \mathrm{km}$ even if some significant shear heating is assumed. It therefore seems highly probable that the isograds were deformed and condensed by postpeak metamorphic tectonics. Last, the fact that all the cooling ages located under the MCT zone as well as below the HHC-like nappes overlying the LH fall approximately on the same trend with respect to structural distance to the MCT suggests that the relevant thrust sheets were probably exhumed jointly and that little slip was taken up on them. Here we emphasize the continuity in cooling ages and peak metamorphic gradient, but we are well aware that the uncertainties on ages, peak metamorphic temperatures and relative structural positions of the samples do not discard the possibility for small discontinuities that may have resulted from recent 


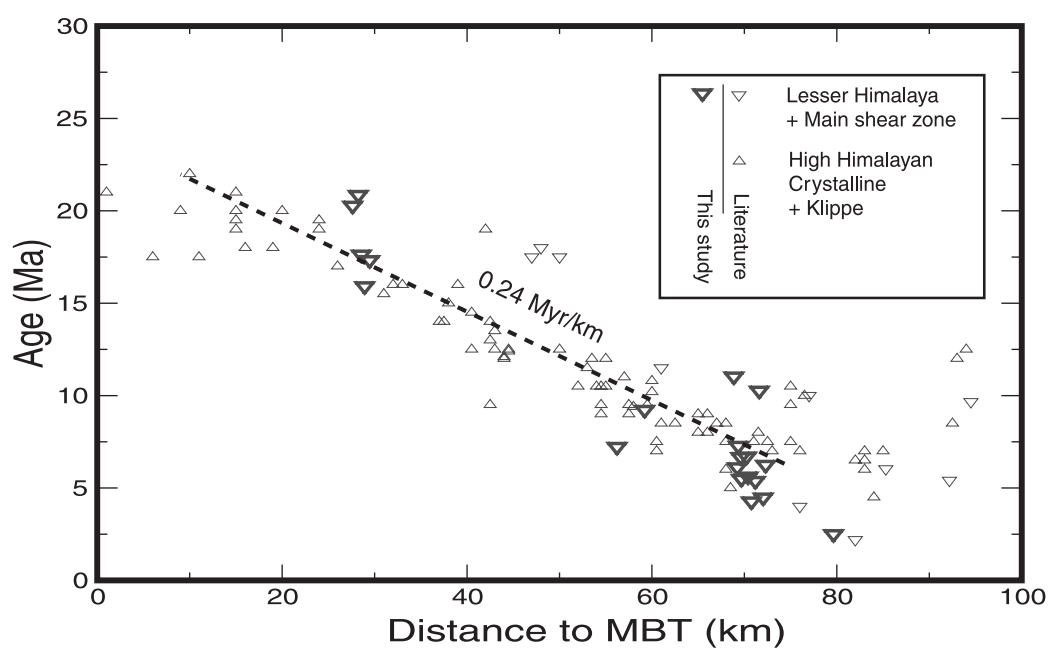

Figure 11. Plot of cooling ages in central Nepal as a function of distance along a N018 ${ }^{\circ} \mathrm{E}$ section. The origin is taken at the MBT. All samples collected from the LH and the main shear zone (triangles down) as well as from the overlying crystalline thrust sheets (triangles up) are reported. Ar/Ar muscovite ages appear to approximately follow a linear trend with ages getting older southward by about $0.24 \mathrm{Myr} / \mathrm{km}$.

reactivation of the MCT or of some faults within the LH. All these observations, together with the Indian affinity of LH rocks have to be taken into account when considering the history of the accretion of the LH to the Himalaya and their subsequent exhumation.

[37] In Figure 12 we present a simple kinematic model in which the LH duplex is assumed to have resulted from southward migration of the midcrustal ramp along the MHT. In this model a new thrust sheet within the LH forms about every $\Delta t$. The new thrust sheet is then incorporated to the overhanging wall leading to a transfer of material from the footwall to the hanging wall. Consequently, a midcrustal ramp is formed implying an apparent southward migration of the ramp at the rate $V_{\text {mig }}=\Delta x / \Delta t$, where $\Delta x$ is the width of the thrust sheet (Figure 12a). According to such a model, the structural organization of the LH units is preserved within each thrust sheet. It results that the metamorphic gradient should then approximately reflect the thermal structure at the time of the accretion. According to calculated thermal structures [e.g., Royden, 1993; Henry et al., 1997], this mechanism cannot produce an inverted gradient as steep as the one observed here. However, the general structure resulting from the stacking of several thrust sheet would lead to an apparently steeper gradient, the cooler material being underplated below rocks that were thrusted along the MHT and were once possibly much hotter. This would lead to an irregular metamorphic gradient. Our data rather show a gradual trend within structurally continuous section so that this mechanism only is not totally satisfactory. We may now consider that once a thrust sheet has been accreted to the footwall it is thrusted up on the ramp and sheared during exhumation. The rocks within the thrust sheet will only cool down so that the peak metamorphic temperatures will reflect the thermal structure just before accretion. Accordingly, the gradients of peak metamorphic temperatures would reflect these deformed paleoisotherms

\section{S}

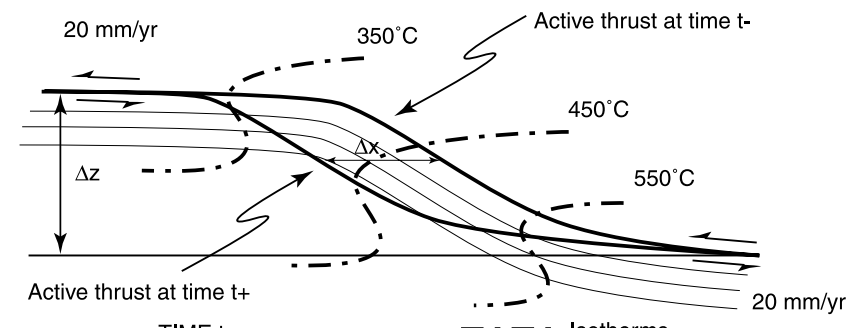
a TIME t

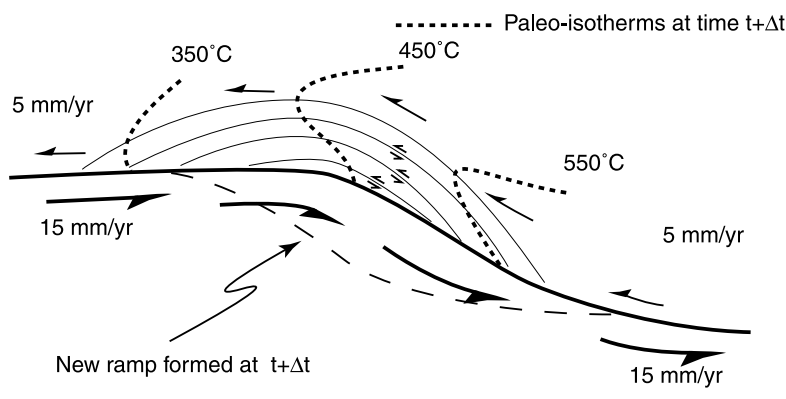

b TIME $t+\Delta t$

Figure 12. Schematic model of duplexing in the Lesser Himalaya. (a) Geometry of the thrust fault at time $t$, just before it migrates to a new position, farther south by $\Delta x$. Thin lines represent lithological units in the Lesser Himalaya within the thrust sheet that is accreted to the hanging wall. Isotherms (dashed line) show the thermal structure at this time. (b) Geometry of the accreted thrust sheet just before the ramp migrates again at time $t+\Delta t$. Arrows show displacements relative to the migrating midcrustal ramp. The paleoisotherms correspond to isotherms in Figure 12a deformed following particles path. They reflect the peak metamorphic temperatures which were reached just before accretion and exhumation of the thrust sheet started. 

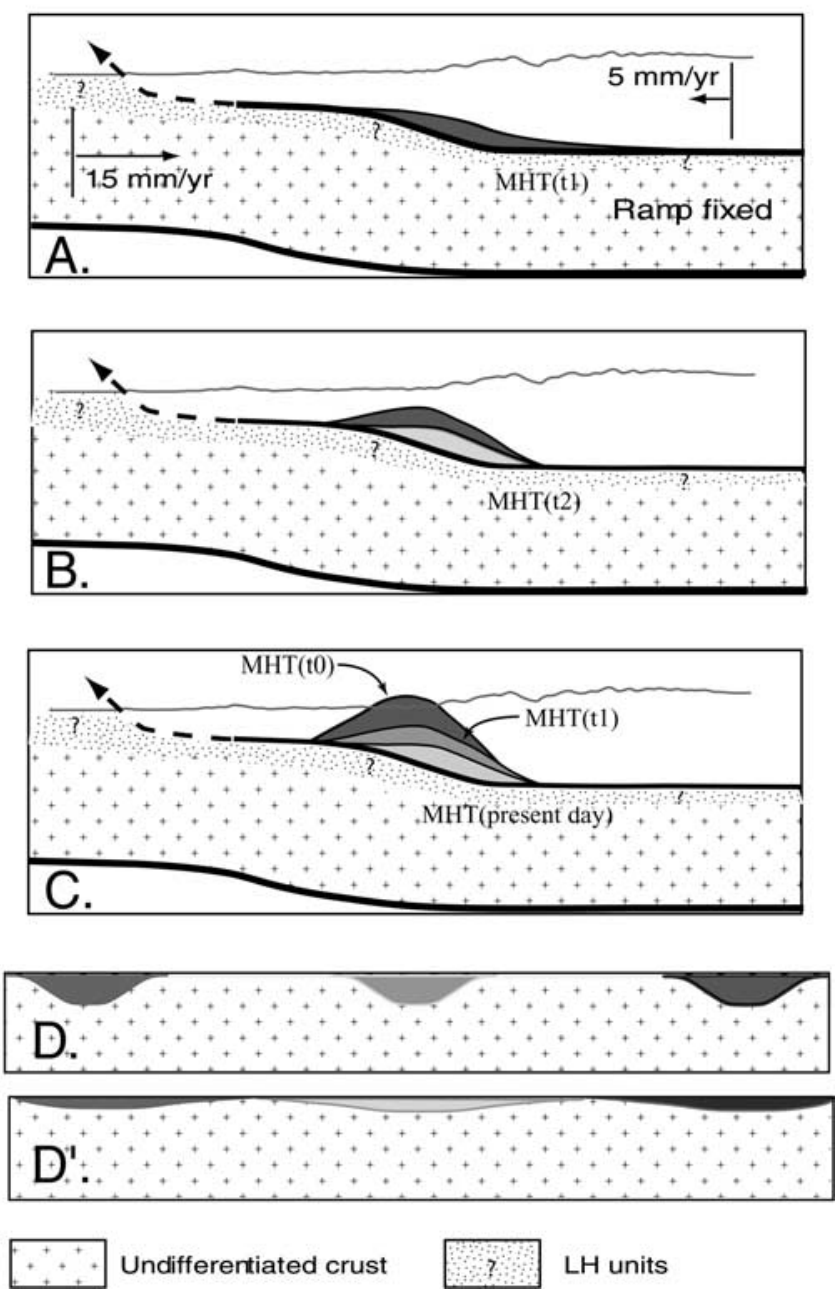

Figure 13. $(\mathrm{a}-\mathrm{c})$ Sequential structural evolution of the Lesser Himalaya. Note that restoring the LH duplex is highly nonunique. The various thrust sheets may be restored in variety of way (D-D') if the footwall is allowed to deform and if the thrust sheets are allowed to experience some combination of pure shear and simple shear during accretion and overthrusting.

(Figure 12b). In this model the inverted metamorphic gradient would mainly be the result of post metamorphic deformation. This process of accretion probably occurred repeatedly over the last 20 Myr. The duplex structure of LH suggests that the southward migration of the ramp results from the succession of discrete events of accretion of slivers scrapped off from the underthrusting Indian crust as shown in Figure 13. The linear trend in Figure 11 does not show the step-like distribution of ages that should then be expected so that the process looks more like a continuous one, given the resolution on cooling ages.

[38] If we now consider a continuous model of accretion and assume that the topography is steady state and controlled by the geometry of the MHT, it is possible to establish some relationships between the rates of overthrusting, $V_{H / R}$, the rate of underthrusting, $V_{F / R}$, the rate of sediment progradation in the foreland, $V_{p r}$, and the gradient of cooling ages (Figure 14). If the steady state topography is taken as the reference, the thermal structure tends toward a steady state geometry with characteristic time of the order of a few Myr, for reasonable values of the erosion rates and thermal characteristics [Royden, 1993], and might also be considered steady state. If erosion is now assumed to be less than the flux of material accreted to the hanging wall, the rocks in the hanging wall moves toward the front of the range and cross the isotherms with an apparent horizontal velocity which is $V_{H / R}=V_{\text {MHT }}-V_{\text {mig }}$, where $V_{\text {MHT }}$ is the slip rate on the MHT (Figure 14). Accordingly cooling ages should decrease approximately linearly with horizontal distance along any section perpendicular to the range and the age gradient should be $V_{H / R}$. From Figure 11, we estimate $1 / V_{H / R}$ to about $0.24 \mathrm{Myr} / \mathrm{km}$. Since $V_{\text {MHT }}$ is estimated around $\sim 20 \mathrm{~mm} / \mathrm{yr}$ [e.g., Lavé and Avouac, 2000], we get that $V_{\text {mig }}$ must be of the order of $15 \mathrm{~mm} / \mathrm{yr}$ (Figure 14). With these assumptions, the footwall is underthrusting the range at a rate $V_{F / R}=V_{\text {mig. }}$. If the geometry of the flexural basin is also steady state (a reasonable assumption if the base level for sedimentation is controlled by the sea level) this rate should correspond to the rate of sediment progradation in the foreland. This is approximately true since this rate is estimated between 10 and $15 \mathrm{~mm} / \mathrm{yr}$ [Lyon-Caen and Molnar, 1985].

[39] According to this model, the mountainous wedge grows primarily by underplating near the brittle-ductile transition, the accreted material consisting of units scrapped off from the top of the footwall but that cannot be restored in a unique manner (Figure 13). In this model, deformation

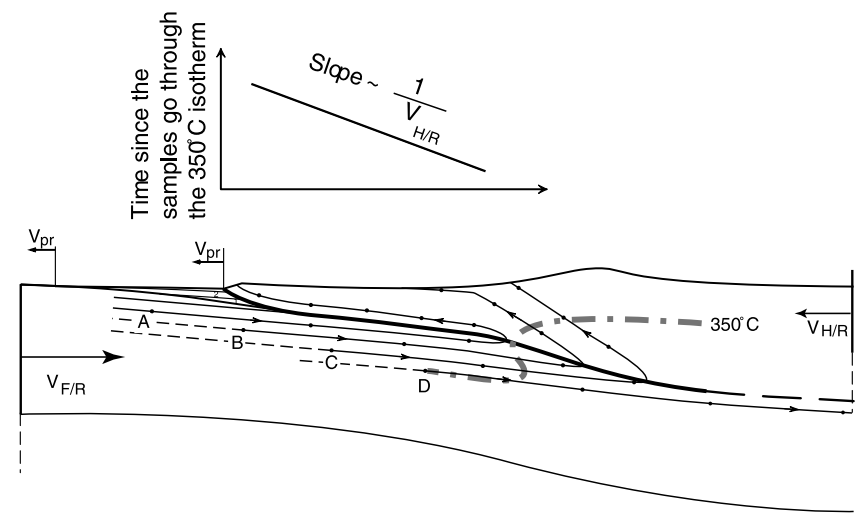

Figure 14. Particle paths in a continuous model of accretion. The reference is taken to be the fault and the topography is assumed steady state meaning that the front of the high range is assumed to coincide with the position of the ramp. $V_{p r}$ is rate of sediment progradation; $V_{H / R}$ is velocity of hanging wall relative to the ramp (overthrusting rate); $V_{F / R}$ is velocity of footwall relative to the ramp (underthrusting rate). The distance between dots corresponds to 5 Myr. The $350^{\circ} \mathrm{C}$ isotherm is shown because it corresponds approximately to the blocking temperature of Ar in muscovite. This kinematics implies that the cooling ages through this isotherm vary approximately linearly along the section with an age gradient $1 / V_{H / R}$ (i.e., inversely proportional to the overthrusting rate). Since the topography is assumed steady state, $V_{p r}$ should be equal to $V_{F / R}$. 


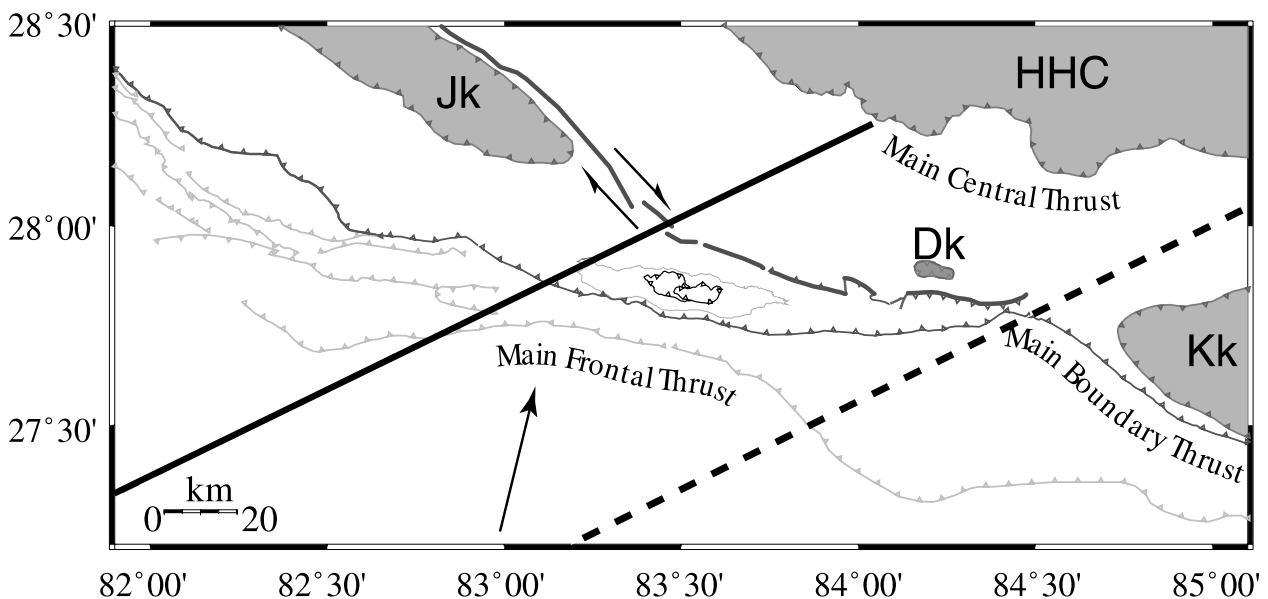

Figure 15. Position of the western edge of the Faizabad ridge at present (thick continuous line) and 10 Myr ago (thick dashed line). The present position is taken from Oil and Natural Gas Commission [1968] and Raiverman et al. [1983] and based on surface geology of Bundelkand massif and subsurface investigations (BGI gravimetry compilation [Bollinger, 2002]). The $10 \mathrm{Ma}$ position was obtained assuming $15 \mathrm{~mm} / \mathrm{yr}$ of underthrusting below the ramp. Abbreviations are $\mathrm{Jk}, \mathrm{Dk}, \mathrm{Kk}$, respectively, for Jajarkot, Damauli, and Kathmandu klippe locations. The arrow shows the azimuth of present convergence across the range.

of the overhanging wall is similar to what would be predicted from the restoration of balanced cross section. The model also bears similarities to the kinematic sketch proposed by Harrison et al. [1998] except that the thrust faults all branch upward on a single shallow crustal decollement rather than reaching the surface. By contrast, the main difference with the kinematics models based on balanced sections is that the footwall is not assumed to be rigid and is allowed to underthrust the flat-ramp-flat geometry of the MHT. We may get an upper bound on the flux of material accreted to the orogenic wedge by assuming a rigid footwall. Let us estimate the flux of material then underplated to the Himalaya for a given MHT geometry. $\Delta z$, the depth difference between the midcrustal and shallow crustal decollements (Figure 13) is given to be around $10 \mathrm{~km}$ as deduced from structural arguments and the pattern of uplift across the range [Lavé and Avouac, 2001]. We hence get a $\Phi_{\text {acc }}$ upper bound of about $150 \mathrm{~m}^{2} / \mathrm{yr}$, corresponding to a rate of accretion of the order of $3 \mathrm{~mm} / \mathrm{yr}$ across a $50 \mathrm{~km}$ long zone of underplating.

\subsection{Implications for Crustal Flux}

[40] The kinematics inferred from this study allow some gross estimate of the flux of crust below Tibet that has resulted from underthrusting of India. The flux of material accreted to the Himalaya being estimated to $150 \mathrm{~m}^{2} / \mathrm{yr}$ at most, we get that out of the about $800 \mathrm{~m}^{2} / \mathrm{yr}$ input due to underthrusting India (assuming an Indian crustal thickness of $40 \mathrm{~km}$ ), about $650 \mathrm{~m}^{2} / \mathrm{yr}$ is underthrusted below the high range. On the other hand, the flux corresponding to overthrusting of HHC amounts to about $5 \times 35=175 \mathrm{~m}^{2} / \mathrm{yr}$. If we exclude any eclogitization of the underthrusting crust, as argued by Cattin et al [2001], the mass of the crust should be preserved and Himalayan tectonics can be estimated to contribute to an input of about $475 \mathrm{~m}^{2} / \mathrm{yr}$ of crust below
Tibet. It might finally be observed that the total flux to the Himalaya resulting from underplating and overthrusting amounts up to $325 \mathrm{~m}^{2} / \mathrm{yr}$. This value is comparable to the $200 \pm 100 \mathrm{~m}^{2} / \mathrm{yr}$ flux of material eroded away from the Himalayan arc that was estimated from sediment budget over the last $10 \mathrm{Myr}$ at [Métivier et al., 1999] or to the value of $250-370 \pm 200 \mathrm{~m}^{2} / \mathrm{yr}$ estimated from current fluvial incision in central Nepal [Lavé and Avouac, 2001]. Uncertainties on these estimates are too large to make any assessment of the balance between crustal flux and erosion in the Himalaya. In addition there may be significant lateral variations of this balance as discussed below.

\subsection{Lateral Differential Exhumation: Basement-Lesser Himalaya Interactions?}

[41] In this model, the flux of material accreted depends on both the southward migration of the thrust system, $V_{\text {mig }}$, and the depth difference, $\Delta z$, between the midcrustal and shallow crustal decollements (Figure 12). The fact that the crystalline thrust sheet show alternating klippes and windows along strike is an indication that this flux probably varies laterally, providing a simple explanation for the succession of windows and klippes (Figures 1a and 2). Where this flux is large we expect a well-developed LH anticlinorium, while where it is low HHC should be dominant. This flux, $\Phi_{\text {acc }}=V_{\text {acc }} \Delta z$, may vary laterally either due to lateral variations in $V_{\text {acc }}$ or $\Delta z$. In central Nepal, the thermochronological data does not suggest significant lateral variations of $V_{\text {mig }}$ so that a variation $\Delta z$ appears to us as the main factor controlling the rate of accretion. Such variations could have resulted from lateral variations in the geometry and structure of the Indian basement.

[42] In Figure 15 we have extrapolated to the north the Faizabad ridge based on the geology of the Indian basement where it crops out and a compilation of subsurface and 
geophysical data [Oil and Natural Gas Commission, 1968] (BGI gravimetry data compiled by Bollinger [2002]). It turns out that the ridge should extend between the Sarda and Gandak depressions that are pre-Cenozoic basins [Raiverman et al., 1983]. The ridge would thus more or less at present coincide with the reentrant of the MFT suggesting some kind of indentation tectonics. This view is moreover supported from the coincidence with the Bari Gad strike slip fault that lies in the Lesser Himalaya north of the ridge. Such strike-slip faults are commonly observed when seamounts or ridges indent an accretionary prism as well as in analogous experiments of indentation [Dominguez et al., 1998, 2000]. Given the obliquity of the ridge, the position of the point of impact with the Lesser Himalaya must have slid gradually westward. It might be additionally proposed that the reentrant of the MBT north of the Chitwan Dun, could have resulted from this indentation tectonics as well (Figure 15). Such a process might explain why the crystalline thrust sheet is well preserved east of this point but has been eroded away between the Kathmandu klippe and the Bari Gad fault that appears to bound to the west the Jajarkot klippe as suggested by structural similarities. To illustrate this process, Figure 15 shows the restored position of the Faizabad ridge at $\sim 10 \mathrm{Ma}$.

\section{Conclusion}

[43] Our study shows that the long-term kinematics of mountain building can be investigated by combining metamorphic thermometry, thermochronology and structural geology. Here we were able to show that the inverted metamorphic gradient, initially documented near the MCT, actually affects the whole of the upper units of the Lesser Himalaya and must have developed over the last $20 \mathrm{Myr}$ as a result of underplating and postmetamorphic deformation. These results support a model in which the Lesser Himalaya units have been accreted to the range mainly by underplating at midcrustal depths. Such a mechanism, which has been proposed in other terranes from the study of the deep structure of exhumed ancient orogens [Dunlap et al., 1997] or in the Alpine context [Mosar, 1999], departs significantly from classical model of mountain growth which generally assume dominantly frontal accretion and thickening by internal shortening of the orogenic wedge. The inverted metamorphic gradient is interpreted as resulting from a combination of underplating and postmetamorphic shearing. Because of the diachronic ages of peak thermal metamorphism, the observed gradient should not be directly compared with the geotherm. Modeling of these data would require computing PT-t paths in a kinematic model accounting for underplating with probably some internal shear during overthrusting and exhumation of the underplated units.

[44] Acknowledgments. This research was funded by the Commissariat à l'Energie Atomique and by the PNRN Centre National pour la Recherche Scientifique program. We thank Department of Mines and Geology, National Seismic Center, for fieldwork assistance. Thermochronological work was accomplished with the invaluable aid of Eric Cowgill. We are most grateful to the Associate Editor, Darrel Cowan, and two anonymous reviewers for their comments and suggestions, which greatly helped improve this manuscript.

\section{References}

Ahmad, T., N. Harris, M. Bickle, H. Chapman, J. Bunbury, and C. Prince (2000), Isotopic constraints on the structural relationships between the lesser Himalayan series and the high Himalayan crystalline series, Garhwal Himalaya, Geol. Soc. Am. Bull., 112, 467-477.

Alsdorf, D., L. Brown, K. D. Nelson, Y. Makovsky, S. Klemperer, and W. Zhao (1998), Crustal deformation of the Lhasa terrane, Tibet plateau, from Project INDEPTH deep seismic reflection profiles, Tectonics, 17, 501-519.

Arita, K. (1983), Origin of the inverted metamorphism of the lower Himalayas, central Nepal, Tectonophysics, 95, 43-60.

Arita, K., and Y. Ganzawa (1997), Thrust tectonics and uplift process of the Nepal Himalaya revealed from fission-track ages (in Japanese with English abstract), J. Geogr., 106, 156-167.

Arita, K., Y. Ohta, C. Akiba, and Y. Maruo (1973), Kathmandu region, in Geology of the Nepal Himalayas, edited by S. Hashimoto, Y. Ohta, and C. Akiba, pp. 99-145, Saikon, Sapporo, Japan.

Arita, K., R. D. Dallmeyer, and A. Takasu (1997), Tectonothermal evolution of the Lesser Himalaya, Nepal: Constraints from ${ }^{40} \mathrm{Ar} /{ }^{39} \mathrm{Ar}$ ages from the Kathmandu Nappe, Island Arc, 6, 372-385.

Auden, J. B. (1935), Traverses in the Himalaya, Rec. Geol. Surv. India, 69, 123-167.

Auden, J. B. (1937), The structure of the Himalaya in Garhwal, Rec. Geol. Surv. India, 71, 407-433.

Beyssac, O., B. Goffé, C. Chopin, and J. N. Rouzaud (2002), Raman spectra of carbonaceous material from metasediments: A new geothermometer, J. Metamorph. Geol., 20, 859-871.
Beyssac, O., L. Bollinger, J. P. Avouac, and B. Goffé (2004), Thermal metamorphism in the Lesser Himalaya of Nepal determined from Raman spectroscopy of carbonaceous material, Earth Planet. Sci. Lett., 225, 233-241.

Bollinger, L. (2002), Déformation de l'Himalaya du Népal, Ph.D. thesis, 400 pp., Univ. Paris-Sud X1, Paris.

Bordet, P. (1961), Recherches Géologiques dans l'Himalaya du Népal, Région du Makalu, 275 pp., Ed. Du Cent. Nat. de la Rech. Sci., Paris.

Bouchez, J. L., and A. Pêcher (1976), Microstructures and quartz preferred orientations in quartzites of the Annapurna area (central Nepal), in the proximity of the Main Central Thrust, Geology, 6, 118-132.

Bouchez, J. L., and A. Pêcher (1981), The Himalayan Main Central Thrust pile and its quartz-rich tectonites in central Nepal, Tectonophysics, 78, 23-50.

Brunel, M. (1975), La nappe du Mahabharat, Himalaya du Népal central, C. R. Acad. Sci., Ser. D, 280, $551-554$.

Brunel, M. (1983), Etude pétro-structurale des chevauchements ductiles en Himalaya (Népal oriental et Himalaya du Nord-Ouest), thèse de doctorat d'état thesis, Univ. Paris VII Denis-Diderot, Paris.

Brunel, M. (1986), Ductile thrusting in the Himalayas: Shear sense criteria and stretching lineations, Tectonics, 5, 247-265.

Brunel, M., M. Colchen, P. Le Fort, G. Mascle, and A. Pêcher (1979), Structural analysis and tectonic evolution of the central Himalaya of Nepal, in Structural Geology of the Himalaya, vol. II, edited by P. S. Saklani, pp. 247-264, Today and Tomorrow's Printers and Publ., New Delhi.
Catlos, E. J., T. M. Harrison, M. J. Kohn, M. Grove, F. J. Ryerson, C. E. Manning, and B. N. Upreti (2001), Geochronologic and thermobarometric constraints on the evolution of the Main Central Thrust, central Nepal Himalaya, J. Geophys. Res., 106, 16,177-16,204.

Cattin, R., and J.-P. Avouac (2000), Modeling of mountain building and the seismic cycle in the Himalaya of Nepal, J. Geophys. Res., 105, 13,389-13,407.

Cattin, R., G. Martelet, P. Henry, J. P. Avouac, M. Diament, and T. R. Shakya (2001), Gravity anomalies, crustal structure and thermo-mechanical support of the Himalaya of central Nepal, Geophys. J. Int., 147, 381-392.

Colchen, M., P. Le Fort, and A. Pêcher (1980), Carte géologique Annapurna-Manaslu-Ganesh, Himalaya du Népal, Cent. Nat. de la Rech. Sci., Paris.

Colchen, M., P. Le Fort, and A. Pêcher (1986), Recherches géologiques dans l'Himalaya du Népal Annapurna, Manaslu, Ganesh Himal, 136 pp., Ed. du Cent. Nat. de la Rech. Sci., Paris.

Coleman, M. E., and K. V. Hodges (1998), Contrasting Oligocene and Miocene thermal histories from the hanging wall and footwall of the South Tibetan detachment in the central Himalaya from ${ }^{40} \mathrm{Ar} /{ }^{39} \mathrm{Ar}$ thermochronology, Marsyandi Valley, central Nepal, Tectonics, 17, 726-740.

DeCelles, P. G., G. E. Gehrels, J. Quade, B. LaReau, and M. Spurlin (2000), Tectonic implications of $\mathrm{U}-\mathrm{Pb}$ zircon ages of the Himalayan orogenic belt in Nepal, Science, 28, 497-499.

DeCelles, P. G., D. M. Robinson, J. Quade, T. P. Ojha, C. N. Garzione, P. Copeland, and B. N. Upreti (2001), Stratigraphy, structure, and tectonic 
evolution of the Himalayan fold-thrust belt in western Nepal, Tectonics, 20, 487-509.

Dominguez, S., S. E. Lallemand, J. Malavieille, and R. Von Huene (1998), Upper plate deformation associated with seamount subduction, Tectonophysics, 293, 207-224.

Dominguez, S., J. Malavieille, and S. E. Lallemand (2000), Deformation of accretionary wedges in response to seamount subduction: Insights from sandbox experiments, Tectonics, 19, 182-196.

Dunlap, W. J., G. Hirth, and C. Teyssier (1997), Thermomechanical evolution of a ductile duplex, $\mathrm{Tec}-$ tonics, 16, $983-1000$

Edwards, R. M. (1995), ${ }^{40} \mathrm{Ar} /{ }^{39} \mathrm{Ar}$ geochronology of the Main Central Thrust (MCT) region: Evidence for late Miocene to Pliocene disturbances along the MCT, Marsyangdi River Valley, west central Nepal Himalaya, J. Nepal Geol. Soc., 10, 41-46.

Ferry, J. M., and F. S. Spear (1978), Experimental calibration of the partitioning of $\mathrm{Fe}$ and $\mathrm{Mg}$ between biotite and garnet, Contrib. Mineral. Petrol., 66, $113-117$.

Fuchs, G., and W. Frank (1970), The geology of west Nepal between the rivers Kali Gandaki and Thulo Bheri, Jahrb. Geol. Bundesanst., 18, 1-103.

Gansser, A. (1964), Geology of the Himalayas, 289 pp., Wiley-Interscience, New York.

Hagen, T. (1969), Report on the geological survey of Nepal Preliminary reconnaissance, $185 \mathrm{pp}$., Mem. de la Soc. Helvétique des Sci. Nat., Zürich.

Hagen, T., and J. P. Hunger (1952), Über geologischpetrographische Untersuchungen in zentral-Nepal, Schweiz Mineral. Petrogr. Mitt., 32, 309-333.

Harrison, T. M., F. J. Ryerson, P. Le Fort, A. Yin, O. M. Lovera, and E. J. Catlos (1997), A late MiocenePliocene origin for the central Himalayan inverted metamorphism, Earth Planet. Sci. Lett., 146, E1E8.

Harrison, T. M., M. Grove, O. M. Lovera, and E. J. Catlos (1998), A model for the origin of Himalayan anatexis and inverted metamorphism, J. Geophys. Res., 103, 27,017-27,032.

Hauck, M. L., K. D. Nelson, L. D. Brown, W. Zhao, and A. R. Ross (1998), Crustal structure of the Himalayan orogen at $\sim 90^{\circ}$ east longitude from Project INDEPTH deep reflection profiles, Tectonics, $17,481-500$.

Heim, A., and A. Gansser (1939). Central Himalaya: Geological Observations of the Swiss Expedition, 1936, 245 pp., Mem. Soc. Helv. Sci. Nat., 73(1), $1-245$.

Henry, P., X. Le Pichon, and B. Goffé (1997), Kinematic, thermal and petrological model of the Himalayas: Constraints related to metamorphism within the underthrust Indian crust and topographic elevation, Tectonophysics, 273, 31-56.

Hodges, K., and D. S. Silverberg (1988), Thermal evolution of the greater Himalaya, Garhwal, India, Tectonics, 7, 583-600.

Hodges, K. V., R. Parrish, and M. P. Searle (1996), Tectonic evolution of the central Annapurna Range, Nepalese Himalaya, Tectonics, 15, 1264-1291.

Hodges, K. V., C. Wobus, K. Ruhl, T. Schildgen, and K. Whipple (2004), Quaternary deformation, river steepening, and heavy precipitation at the front of the Higher Himalayan ranges, Earth Planet. Sci. Lett., 220, 379-389.

Holdaway, M. J., B. Mukhopadhyay, M. D. Dyar, C. V. Guidotti, and B. L. Dutrow (1997), Garnet-biotite geothermometry revised: New Margules parameters and a natural specimen data set from Maine, $A m$. Mineral., 82, 582-595.

Hubbard, M. S. (1989), Thermobarometric constraints on the thermal history of the Main Central Thrust zone and Tibetan slab, eastern Nepal, J. Metamorph. Geol., 7, 19-30.

Hubbard, M. S. (1996), Ductile shear as a cause of inverted metamorphism: Example from the Nepal Himalaya, J. Geol., 104, 493-499.

Huyghe, P., A. Galy, J.-L. Mugnier, and C. FranceLanord (2001), Propagation of the thrust system and erosion in the Lesser Himalaya: Geochemical and sedimentological evidence, Geology, 29 $1007-1010$.

Jaupart, C., and A. Provost (1985), Heat focussing, granite genesis and inverted metamorphic gradient in continental collision zones, Earth Planet. Sci. Lett., 73, 385-397.

Johnson, M. R. W., G. J. H. Oliver, R. R. Parrish, and S. P. Johnson (2001), Synthrusting metamorphism, cooling, and erosion of the Himalayan Kathmand Complex, Nepal, Tectonics, 20, 394-415.

Kaneko, Y. (1995), Thermal structure in the Annapurna region, central Nepal Himalaya: Implication for th inverted metamorphism, J. Mineral. Petrol. Econ. Geol., 90, 143-154.

Kawamitsu, K., and D. Hayashi (1991), Geology and three dimensional finite strain analysis aroun Annapurna Himal, central Nepal, Bull. Coll. Sci. Univ. Ryukyus, 52, 39-54

Lavé, J., and J.-P. Avouac (2000), Active folding of fluvial terraces across the Siwaliks Hills, Himalayas of central Nepal, J. Geophys. Res., 105, 5735 5770.

Lavé, J., and J. P. Avouac (2001), Fluvial incision and tectonic uplift across the Himalayas of central Nepal, J. Geophys. Res., 106, 26,561-26,592.

Le Fort, P. (1975), Himalaya: the collided range: Present knowledge of the continental arc, Am. J. Sci. $275 A, 1-44$

Le Fort, P. (1986), Metamorphism and magmatism during the Himalayan collision, in Collision Tectonics, edited by M. P. Coward and A. C. Ries, Geol. Soc. Spec. Publ., 19, 159-172.

Le Fort, P., A. Pêcher, and B. N. Upreti (1986), A section through the Tibetan Slab in central Nepal (Kali Gandaki valley): Mineral chemistry and thermobarometry, in Evolution des Domaines Orogéniques d'Asie Méridionale (de la Turquie à l'Indonésie), vol. 47, edited by P. Le Fort, M. Colchen, and C. Montenat, Sci. Terre Mem., 47, 211-228.

Lemonnier, C., G. Marquis, F. Perrier, J.-P. Avouac, G. Chitrakar, B. Kafle, S. Sapkota, U. Gautam, D. Tiwari, and M. Bano (1999), Electrical structure of the Himalaya of central Nepal: High conductivity around the mid-crustal ramp along the MHT, Geophys. Res. Lett., 26, 3261-3264.

Lyon-Caen, H., and P. Molnar (1985), Gravity anomalies, flexure of the Indian plate and the structure, support and evolution of the Himalaya and Ganga Basin, Tectonics, 4, 513-538.

Macfarlane, A., K. V. Hodges, and D. Lux (1992), A structural analysis of the Main Central Thrust zone, Langtang National Park, central Nepal Himalaya, Geol. Soc. Am. Bull., 104, 1389-1402.

Makovsky, Y., et al. (1996), Structural elements of the southern Tethyan Himalaya crust from wide-angle seismic data, Tectonics, 15, 997-1005.

Mallet, F. R. (1874), On the geology, etc., of the Darjiling district and the Western Duars, Mem. Geol. Surv., 11

McDougall, I., and T. M. Harrison (1999), Geochronology and Thermochronology by the ${ }^{40} \mathrm{Ar}{ }^{39}$ Ar Method, 269 pp., Oxford Univ. Press, New York

Medlicott, H. B. (1864), On the geological structure and relations of the southern portion of the Himalayan range between river Ganges and Ravee, Mem Geol. Surv. India, 3, 1-206.

Meigs, A. J., D. W. Burbank, and R. A. Beck (1995), Middle-late Miocene $(>10 \mathrm{Ma})$ formation of the main boundary thrust in the western Himalaya, Geology, 23, 423-426.

Metcalfe, R. P. (1993), Pressure, temperature and time constraints on metamorphism across the Main Central Thrust zone and High Himalayan slab in the Garhwal Himalaya, in Himalayan Tectonics, edited by P. J. Treloar and M. P. Searle, Geol. Soc. Spec. Publ., 74, 485-509.

Métivier, F., Y. Gaudemer, P. Tapponnier, and M. Klein (1999), Mass accumulation rates in Asia during the Cenozoic, Geophys. J. Int., 137, 280-318.

Molnar, P., and P. England (1990), Temperatures, heat flux, and frictional stress near major thrust fault, J. Geophys. Res., 95, 4833-4856.
Mosar, J. (1999), Present day and future tectonic underplating in the western Swiss Alps: Reconciliation of basement/wrench-faulting and decollement folding of the Jura and Molasse basin in the Alpine foreland, Earth Planet. Sci. Lett., 173, 143-155.

Najman, Y., and E. Garzanti (2000), Reconstructing early Himalayan tectonic evolution and paleogeography from Tertiary foreland basin sedimentary rocks, northern India, Geol. Soc. Am. Bull., 112 , $435-449$

Ohta, Y., C. Akiba, K. Arita, and Y. Maruo (1973), Pokhra-Gurka region, in Geology of the Nepal Himalayas, edited by S. Hashimoto, Y. Ohta, and C. Akiba, pp. 159-188, Saikon, Sapporo, Japan.

Oil and Natural Gas Commission (1968), Tectonic Map of India, edited by B. S. Negi and N. A. Eremenko, Dehra Dun, India.

Oldham, R. D. (1883), The geology of Jaunsar and the lower Himalayas, Rec. Geol. Surv. India, 16, $193-$ 198

Parrish, R. R., and K. V. Hodges (1996), Isotopic constraints on the age and provenance of the Lesser and Greater Himalayan sequences, Nepalese Himalaya, Geol. Soc. Am. Bull., 108, 904-911.

Pêcher, A. (1975), The Main Central Thrust of the Nepal Himalaya and the related metamorphism in the Modi-Khola cross-section (Annapurna Range), Himal. Geol., 5, 115-132.

Pêcher, A. (1977), Geology of the Nepal Himalaya: Deformation and petrography in the Main Central Thrust Zone, in Ecologie et Géologie de l'Himalaya, vol. 268, pp. $301-318$, Ed. du Cent. Nat. de la Rech. Sci., Paris.

Pêcher, A. (1978), Déformation et métamorphisme associés à une grande zone de cisaillement, exemple du grand chevauchement central Himalayen (MCT), transversales des Annapurnas et du Manaslu, Népal, thèse d'état thesis, 310 pp., Univ. de Grenoble, Grenoble, France.

Pêcher, A. (1989), The metamorphism in central Himalaya, J. Metamorph. Geol., 7, 31-41.

Pêcher, A., J. L. Bouchez, and P. Le Fort (1991), Miocene dextral shearing between Himalaya and Tibet, Geology, 19, 683-685.

Powers, P. M., R. J. Lillie, and R. S. Yeats (1998), Structure and shortening of the Kangra and Dehra Dun reentrants, Sub-Himalaya, India, Geol. Soc Am. Bull., 110, 1010-1027.

Rai, S. M. (1998), Étude structurale, métamorphique, géochimique et radiochronologique des nappes de Katmandou et du Gosainkund, Himalaya du Népal central, thèse de $3 \mathrm{e}$ cycle thesis, 244 pp., Univ. Joseph-Fourier, Grenoble, France.

Rai, S. M., S. Guillot, P. Le Fort, and B. N. Upreti (1998), Pressure-temperature evolution in the Kathmandu and Gosainkund regions, central Nepal, J. Asian Earth Sci., 16, 283-298.

Raiverman, V., S. V. Kunte, and A. Mukherjea (1983), Basin geometry, Cenozoic sedimentation and hydrocarbon prospects in north western Himalaya and Indo-Gangetic plains, Pet. Asia J., 6, 6792

Reddy, S. M., M. P. Searle, and J. A. Massey (1993), Structural evolution of the high Himalayan gneiss sequence, Langtang valley, Nepal, in Himalayan Tectonics, edited by P. J. Treloar and M. P. Searle, Geol. Soc. Spec. Publ., 74, 375-389.

Robinson, D. M., P. G. DeCelles, P. J. Patchett, and C. N. Garzione (2001), The kinematic evolution of the Nepalese Himalaya interpreted from $\mathrm{Nd}$ isotope, Earth Planet. Sci. Lett., 192, 507-521.

Rolfo, F., C. D'anna, L. Mangiapane, and B. Lombardo (2001), A section through the MCT zone, Bhote Kosi valley, Nepal Himalaya (abstract), in 16th Himalaya-Karakorum-Tibet Workshop, J. Asian Earth Sci., 19-3A, 54-55.

Royden, L. H. (1993), The steady state thermal structure of eroding orogenic belts and accretionary prisms, J. Geophys. Res., 98, 4487-4507.

Sakai, H. (1983), Geology of the Tansen group of the Lesser Himalaya in Nepal, Mem. Fac. Sci. Kyushu Univ., Ser. D, 25, 27-74. 
Schelling, D., and K. Arita (1991), Thrusts tectonics, crustal shortening and the structure of the far-eastern Nepal Himalaya, Tectonics, 10, 851-862.

Searle, M. P., D. J. Waters, and B. J. Stephenson (2002), Pressure-temperature-time path discontinuity in the Main Central thrust zone, central Nepal: Comment, Geology, 30, 479-480.

Sharma, T., D. R. Kansakar, and K. Kizaki (1984), Geology and tectonics of the region between Kali Gandaki and Bheri rivers in central west Nepal, Bull. Coll. Sci. Univ. Ryukyus, 38, 57-102.

Srivastava, P., and G. Mitra (1996), Deformation mechanisms and inverted thermal profile in the North Almora Thrust mylonite zone, Kumaon lesser Himalaya, India, J. Struct. Geol., 18, 27-39.

Stephenson, B. J., D. J. Waters, and M. P. Searle (2000), Inverted metamorphism and the Main Central Thrust: Field relations and thermobarometric constraints from the Kishtwar Window, NW Indian Himalaya, J. Metamorph. Geol., 18, $571-590$.
Stöcklin, J. (1980), Geology of Nepal and its regional frame, J. Geol. Soc. London, 137, 1-34.

Stöcklin, J., and K. D. Bhattarai (1977), Geology of the Kathmandu area and central Mahabharat range, Nepal, Himalayan report, 86 pp., Nepal Dept. of Mines and Geol., Lainchur, Kathmandu.

Stöcklin, J., K. D. Bhattarai, V. S. Chettri, and A. N. Bhandari (1980), Geologic map of Kathmandu area and Central Mahabharat Range, Dept. of Mines and Geol., Kathmandu, Nepal.

Upreti, B. N. (1996), Stratigraphy of the western Nepa Lesser Himalaya: A synthesis, J. Nepal Geol. Soc. 13, 1996.

Upreti, B. N. (1999), An overview of the stratigraphy and tectonics of the Nepal Himalaya, J. Asian Earth Sci. 17, 577-606.

Upreti, B. N., and P. Le Fort (1999), Lesser Himalaya crystalline nappes of Nepal: Problems of their origin, Spec. Pap. Geol. Soc. Am., 328, 225-238.

Vannay, J. C., and K. V. Hodges (1996), Tectonometamorphic evolution of the Himalayan metamorphic core between the Annapurna and Dhaulagiri, central Nepal, J. Metamorph. Geol., 14, 635-656.

Whittington, A., G. Foster, N. Harris, D. Vance, and M. Ayres (1999), Lithostratigraphic correlations in the western Himalaya-An isotopic approach, Geology, 27, 585-588.

J. P. Avouac and L. Bollinger, Laboratoire Détection et Géophysique, CEA, BP12, F-91680 Bruyères le Châtel, France. (laurent.bollinger@cea.fr)

O. Beyssac and B. Goffé, Ecole Normale Supérieure, Laboratoire de Géologie, 24 rue Lhomond, F-75005 Paris, France.

E. J. Catlos, M. Grove, and T. M. Harrison, Institute of Geophysics and Planetary Physics, University of California, 595 Charles Young Drive East, 3806 Geology Building,Box 951567, Los Angeles, CA 90095-1567, USA

S. Sapkota, Department of Mines and Geology, National Seismic Center, Lainchur, Kathmandu, Nepal. 